Historic, Archive Document

Do not assume content reflects current scientific knowledge, policies, or practices. 



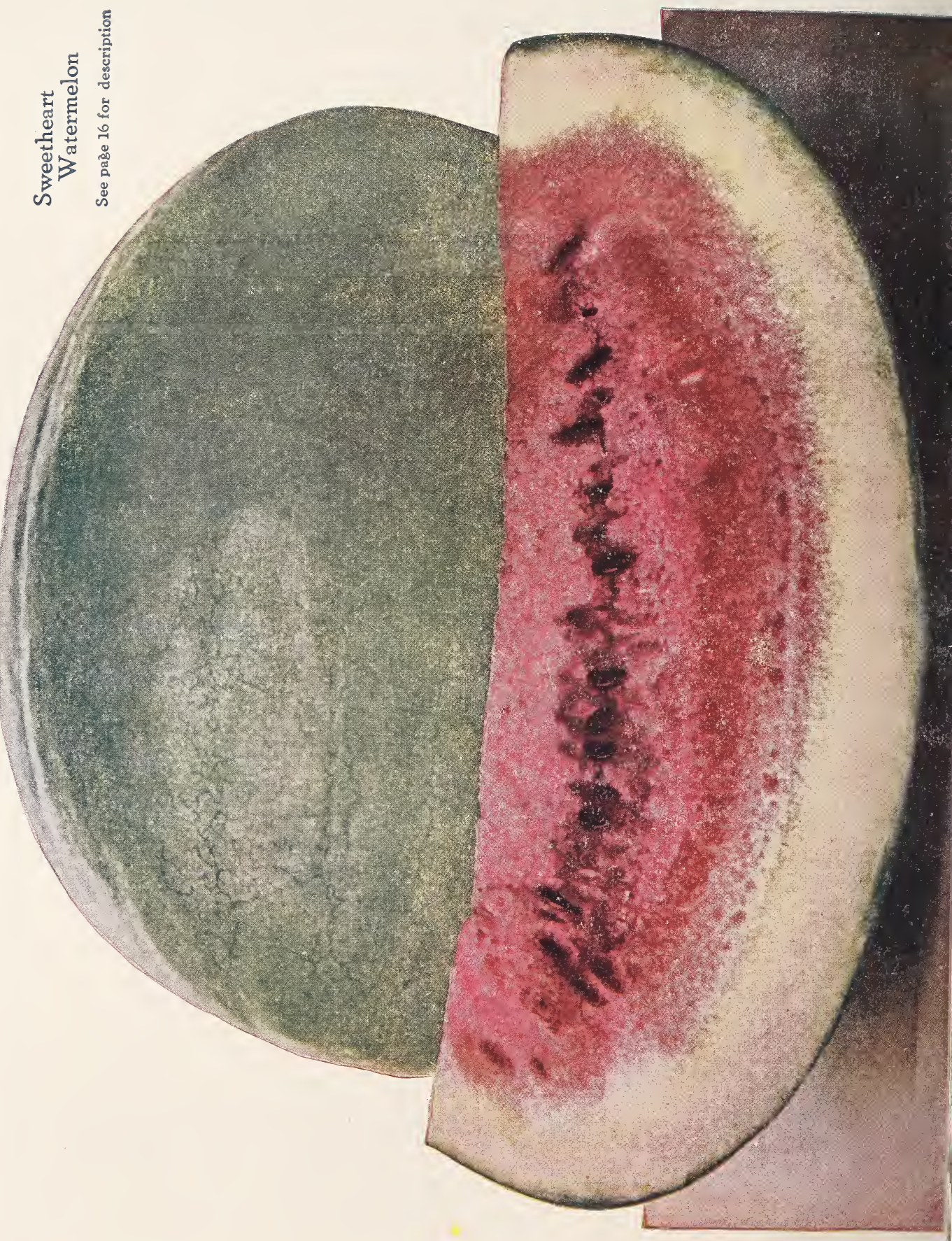




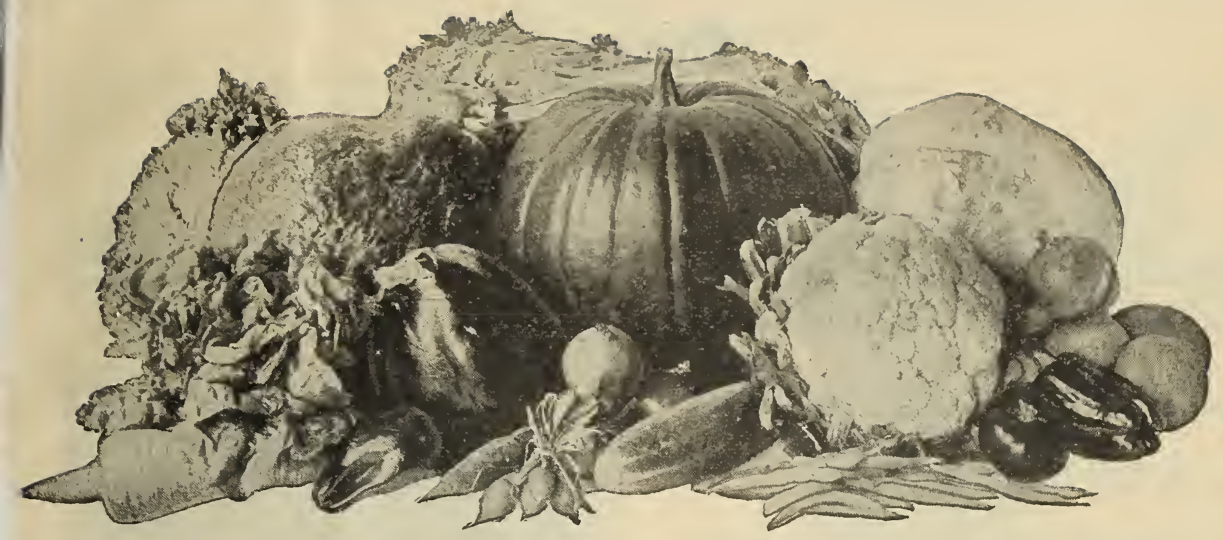

\section{The Vegetable Garden}

Our catalogu's describes all of the best standard varieties and the newer kinds that have become popular.

It is surprising how small a piece of ground is needed to supply a family of average size with fresh vegetables through the whole season. A piece of ground, say, thirty feet by forty feet, will do it. In these days of high prices there are many sorts of vegetables that it more than pays to grow at home. In comparison with the ridiculously small cost, the return surely does warrant the effort.

\section{Vegetable Seeds}

\section{ASPARAGUS}

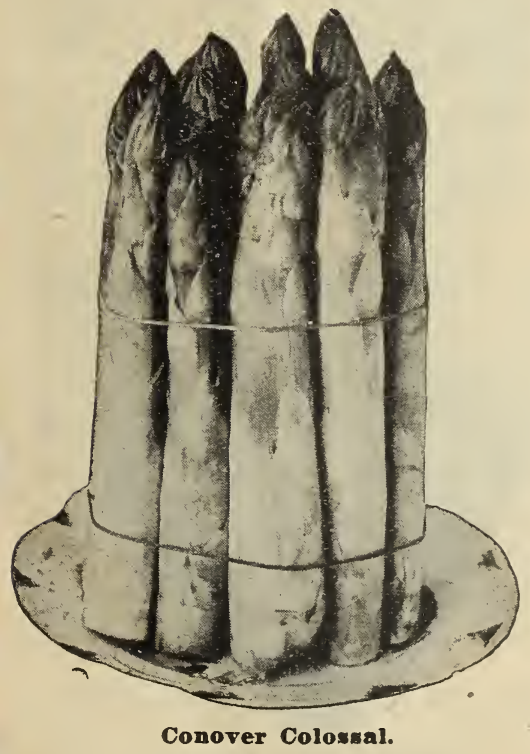

BARR MAMMOTH-Has very large, tender stalks of very light color.

CONOVER COLOSSAL-The most approved and standard sort; large.

COLUMBIAN MAMMOTH WHITE-A choice variety; stalks white; good quality.

ROOTS-Two-year-old,

\section{ARTICHOKE}

CULTURE-Deep, rich sandy loam with plenty of well-rotted manure. Sow seeds in April and May, and when large enough, transplant into rows three "o four feet apart and two feet in the rows. They reach maturity the second year. Cover with litter when cold weather commences, first tying up the leaves so that they will occupy less space, and in spring fork in a dressing of manure. It is an excellent vegetable and easily grown, thriving in any situation, providing the heads are cut off and used as they get ready.

FRENCH GLOBE-The standard and best variety.

JERUSALEM ARTICHOTE-Tubers only: used for pickling and stock. 


\section{Beets \\ Ready for Table Use in 40 to 60 Days. \\ Garden Beets for Table Use}

CULTURE-Sow as early in the spring as the ground can be worked and every two weeks after for a succession up to the first weeks of July. For general crop sow about the middle of May. The soil should be light, sandy loam, well enriched with stable manure and plowed and harrowed until very fine. Sow in drills one foot to fifteen inches apart, and when well up, thin to from four to six inches. The young beets pulled out of the rows are excellent used as Spinach.

EARLY MODEL-Extremely e a r I y; perfect globe, deepest blood red.

BASTIAN-A very early light colored turnip beet; fine market variety.

CROSBY'S EGYPTIAN-An extra early dark blood, round, not flat.

C R I M O N GL O B E-Fine shape, smooth, dark red skin, rich deep crimson flesh.

DETROIT DARK RED-Very choice deep red; fine shaped beet; see illustration on back inside cover page.

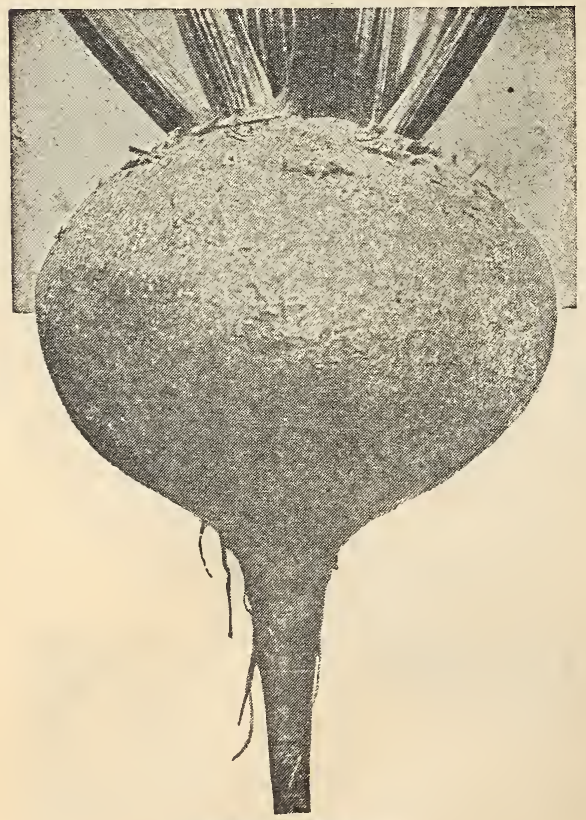

Crosby's Egyptian

DEWING EARLY-Of fine form, flavor and good for market.

EARLY TURNIP BASGANO-Grows to a large size, tops large, flesh pink, zoned with white; very sweet.

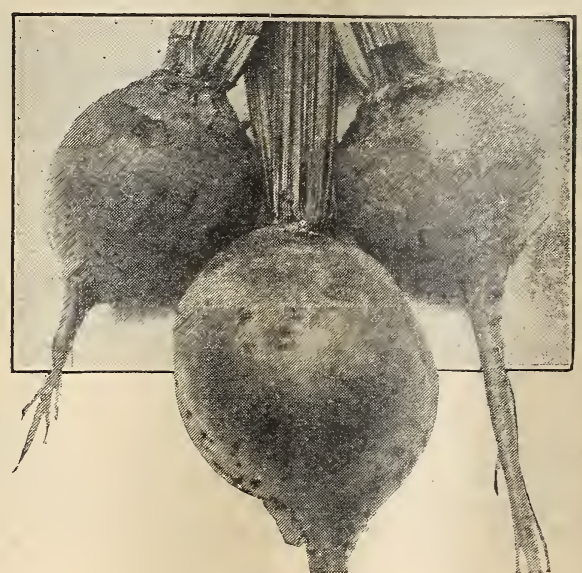

Crimson Globe

EARLY BLOOD TURNIP-Dark red and of fine flavor; productive, standard sort.

EDMAND BLOOD TURNIP-A market gardener's strain of great regularity in shape; deep blood skin and very dark flesh of best quality.

EXTRA EARLY EGYPTIAN-V e $r$ y early and dark blood color, rather flat.

EXTRA EARLY E CLI P S E-Very early; round rooted and dark red; one of the very best.

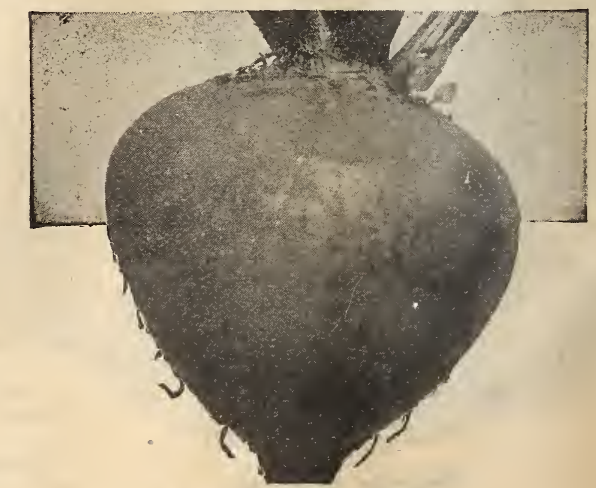

Edmand Blood Turnip 


\section{BEETS-Continued}

H A L F L O N G B L O O D-Fine dark strain; distinct variety: smooth and handsome.

LENTZ EXTRA EARLY TURNIP-A large small top, round beet, fine strain.

LONG SMOOTH BLOOD-A good late variety; dark red; tender and sweet.

SWISS CHARD OR SILVER-Cultivated for its leaves; mid rib, stewed and served as asparagus, the rest served as spinach.

\section{Mangel-Wurzel, Sugar Etc.}

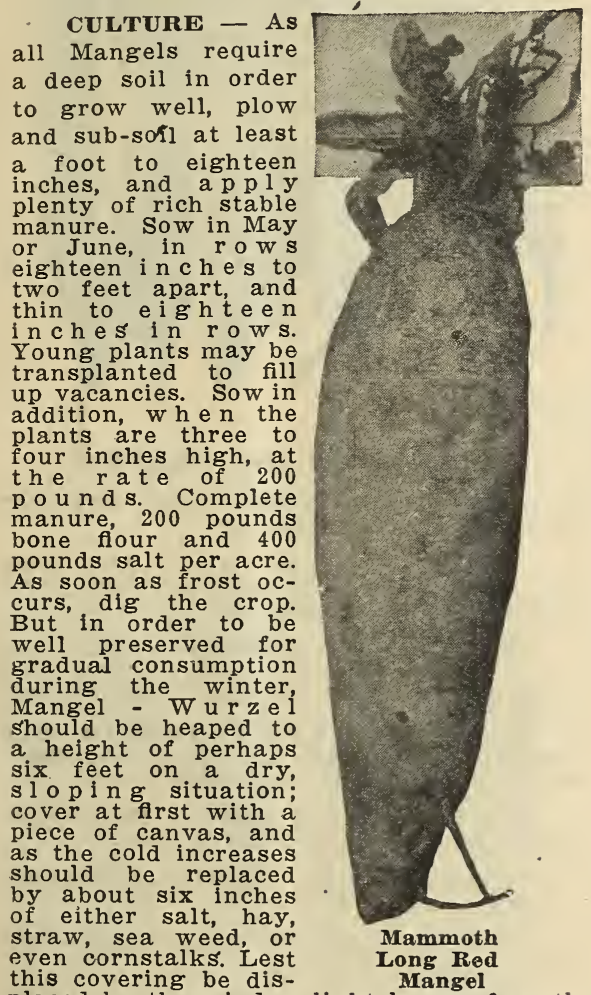
placed by the wind, a light layer of earth is necessary. So soon as this surface soil becomes frozen about six or eight inches more of earth should be placed over the entire heap. By following up this gradual process of covering, all danger of heating will be obviated, and the roots will keep in perfect order. Sow from four to flve pounds per acre.

GOLDEN TANKARD MANGEL-WURZEL-A bright yellow; handsome and sweet, and very productive; tops small, roots large.

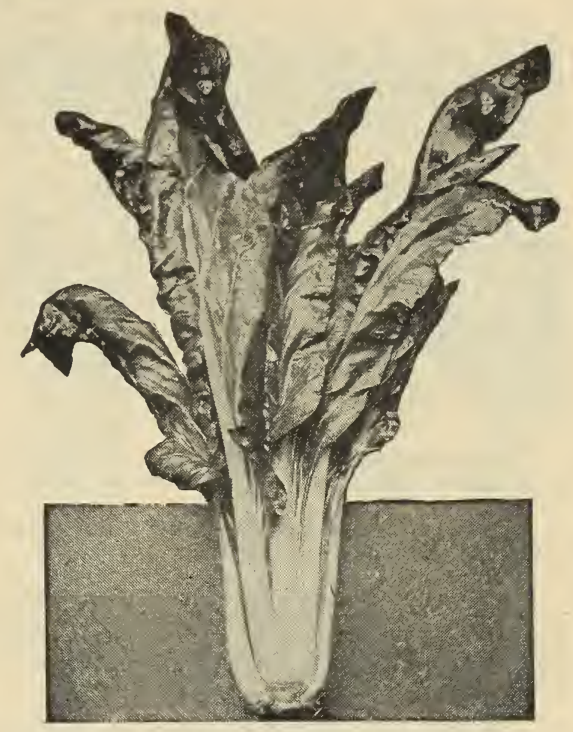

Swiss Chard

GIANT I E EDIN G S U GA R-This unites the large size of the Mangel with the greater feeding value of the Sugar Beet. The roots are always regular and uniform, broad at the top with a full and slightly tapering shoulder.

KLEIN WANZLEBEN-Larger than Vilmorin; good sugar beet; very hardy.

LANE'S SUGAR-For sugar making or stock feed.

LONG YELLOW MANGEL-WURZELGood main crop sort.

MAMMOTH LONG RED MANGELWURZEL-Very large, selected strain, the largest and finest roots. The standard.

ORANGE GLOBE MANGEL-WURZEL -Of distinct shape; one of the most productive; hardy, vigorous.

RED GLOBE MANGEL-WURZELSimilar to the Yellow Globe; productive.

VILMORIN IMPROVED SUGAR-A much improved strain of the preceding; very valuable as a sugar-producing beet

WHITE SUGAR BEET-Grow: to a large size, and is useful for making sugar as well as for stock feeding 


\section{Beans}

CULTURE. Do not plant them until the ground becomes dry and warm. Bush Beans may be planted about 2 inches deep in drills from 24 to 30 inches apart according to variety and soil, placing the seed 3 inches apart or 4 seeds in hills 24 inches apart each way; 2 pounds per 100 foot drill.

Cultivation should be frequent until the plants begin to bloom, but only when the foliage is dry, for if disturbed when wet the vines will rust.

\section{Dwarf or Snap Bean}

BURPEE'S S T R I N G L E S S GREEN POD-This new bean produces a vine similar to Red Valentine, but develops pods to edible condition two to three days earlier than Valentine. This advances the Stringless Green Pod to the first rank among table beans. Pods are stringlessabsolutely so-the pods breaking as short and free as pipe stems; enormously productive.

DWARF HORTICULTURAL-Late and productive; fine either shelled or green.

EARLY MOHAWK-Long, flat and straight pods; very hardy.

EXTRA EARLY RED VALENTINEEarly strain of this popular round pod bean, nothing superior to this in snaps among the green podded sorts; many prefer to Wax varieties.

GIANT STRINGLESS-Similar to Burpee Stringless; lighter in color; hardy, and highest quality.

LOW'S CHAMPION-A very productive variety, with perfectly stringless, large, green flat pods.

LONG YELLOW SIX WEEKS-Early; the leading market sort; full; flat, green pods; good quality.

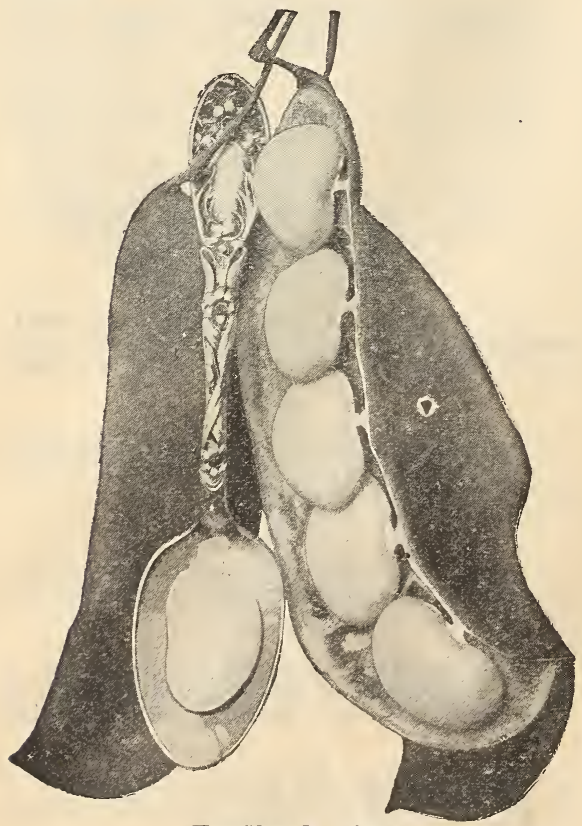

Fordhook Lims.

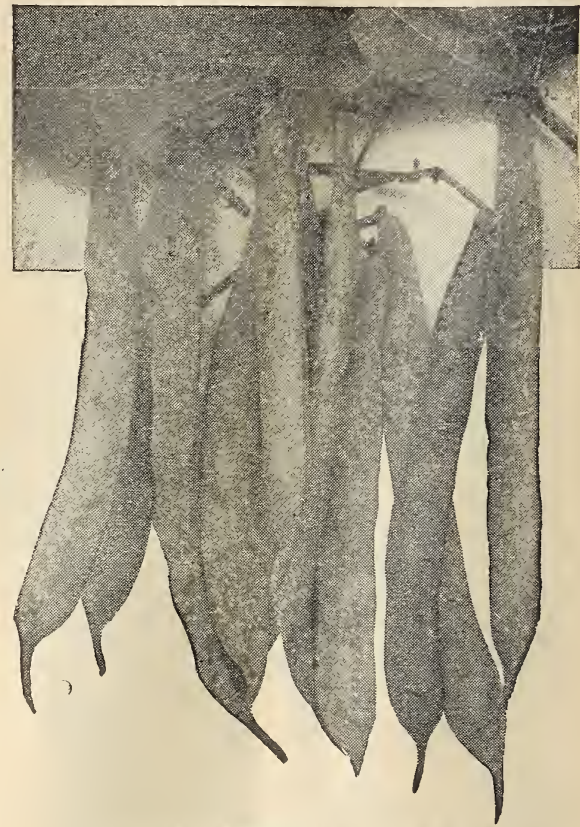

Burpee's Stringleas Green Pod

MISSOURI WONDER-Late; very productive; disease resisting.

PROLIFIC TREE-(Navy)-The most prolific bean known, bean not large, but fine shape, cooks easy.

REFUGEE, OR 1,000-TO-1-Medium to late; very productive and tender, and largely grown for main crop; round pod.

ROU N D, EA RLY YELLOW SIX WEEKS - Resembles the Mohawk; sable in color; flat pods; a popular one,

T E N N S S E E GREEN POD-Pods large, flne flavor, popular in south.

WHITE KIDNEY OR ROYAL DWARF -Fine winter shell bean.

WHITE NAVY OR PEA BEAN-Seed white; nearly round.

BURPEE BUSH LIMA-A bush form of the large Pole Lima, the beans being large and flat, like those of that variety. It is very productive and its dwarf character is well established.

DREER'S BUSH-Immensely productive; may be used as a shell bean or snap bean; broad, flat pods.

FORDHOOK BUSH LIMA-Early; very productive; best quality.

HENDERSON'S BUSH LIMA O R SIEVA-Productive; a very early bean. 


\section{BEANS-Continued}

CHALLENGE BLACK WAX-An extra early strain of the Dwarf Black Wax.

DETRoIT WAX - Very much like Golden Wax, but less liable to rust.

CURRIE'S RUST-PROOF WAX-VIgorous and hardy; productive.

FLAGEOLET WAX-Flat, y e 110 w, stringless pods of great length and oreadth; exceedingly productive.

GOLDEN-EYED WAX-Very ha $\mathrm{rdy}$ and prolific, with flat, yellow pods; very early and exceptionally free from rust; a very desirable and popular sort.

GRINNELL'S IMPROVED GOLDEN WAX-Very early; round golden pods.

IMPROVED PROLIFIC BLACK WAX -Very early and prolific. The pods are round, full, stringless and of fine quality.

REFUGEE WAX-A perfect Refugee with long, round yellow wax pods; suitable for early or late sowing, and an immense yielder.

ROYAI, PURPLE WAX-See description, page 2.

WARDWELL KIDNEY WAX-Extra early; purely wax, pods long, flat and remarkably free from rust.

WHITE WAX-Flat, yellow pods; very handsome, vines small.

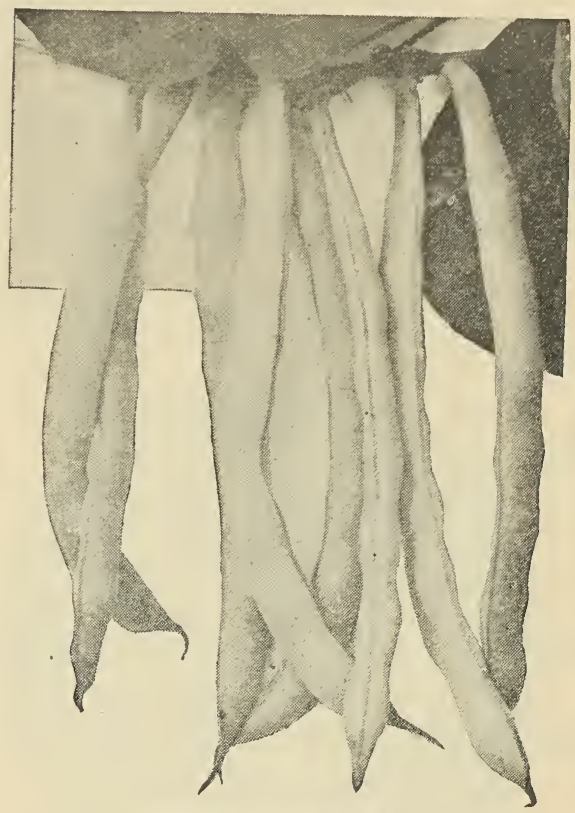

Improved Golden Wax

\section{Pole Beans}

CULTURE-The pole bean climbs, sometimes needing a little training over any support given it. A good practice is to set firmly in the ground every three or four feet each way, poles that are, when set, about six feet high.

Ready for Use in 70 to 90 Days.

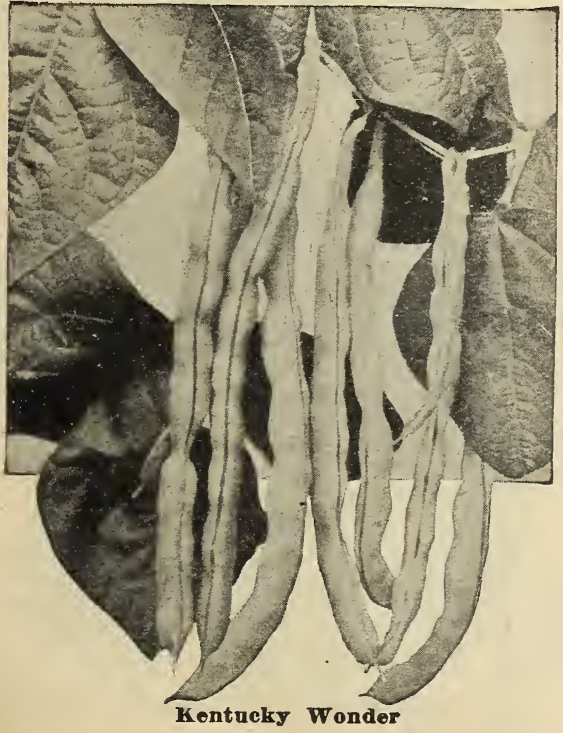

GOLDEN CARMINE PODDED HORTICULTURAL-In this new strain we have a wonderful, robust grower. The pods are large, stringless, bright golden color when very young. As they approach full size, they are mottled and streaked with an unusually bright carmine color on the golden, which gives the pods when ready for market, a beautiful and attractive appearance.

LARGE WHITE LIMA-L a $\mathrm{rg}$ e 1 y grown and highly esteemed.

KING OF THE GARDEN LIMALarge in pod and bean; productive.

DREER LIMA-Thick and of fine quality; early variety.

EARLY JERSEY LIMA-A few days earlier than the large Lima.

HORTICULTURAL LIMA-A cross between the Horticultural and Dreer Lima. It matures much earlier than the Lima.

HORTICULTURAL OR SPECKLED CRANBERRY - Showy, excellent either as a snap or shell bean.

SPECKLED CUT-SHORT OR CORN HILL-Used for planting among corn; one of the best. 


\section{BEANS-Continued}

DUTCH CASE IRNIFE-Pods long, green and flat; can be either snapped or shelled.

GOLDEN ANDALUSIA (New)-Most productive of all the pole varieties; beans pure white, round.

IKENTUCKY WONDER (Old Homestead)-Pods green, very long, very prolific.

LAZY WIFE-Great favorite; pod from four to six inches long, stringless, rich, buttery flavor; beans are white and make a fine shell bean; pods remain green and tender long.

MONT D'OR OR GOLDEN CLUSTEREarly, productive; golden wax pods six to eight inches long.

SCARLET RUNNER-A popular English Pole Bean; very ornamental.

WHITE CREASE BACK-Long, round, stringless pod; fleshy and tende:

WHITE KENTUCKY WONDER-Very fleshy and tender; stringless; of high quality.

WHITE DUTCH R U N N E R-Same habit as the Scarlet Runner; flowers and beans being white.

\section{BROCOLLI}

CULTURE-Sow early sorts as soon as the ground can be worked in the spring, in shallow drills, drawn three or four inches apart. Plant out two feet apart each way when the plants are about four inches high. Cultivate the same as cabbage, in rich soil. Use the same remedy for insect attacks as are recommended for cabbage. The following are sorts best adapted to this climate, and the only ones which succeed generally; they are excellent and deserve much wider culture than is usual in this country.

EARLY WHITE CAPE-Best flavor; very hardy; small.

\section{BRUSSELS SPROUTS}

CULTURE-Sow in May in the same manner as Cauliflower and transplant in July, one foot apart, in the rows, which should be one and one-half feet apart. In gardens, both large and small, Brussels Sprouts are, without exception, the very best winter vegetable that can be grown. The real sprout is not much larger than a marble, and as firm and hard almost as the stalk itself. These are the sorts which cooks prefer. They strip off the outer covering, cook them whole, and serve them up artistically in that fashlon. When cooked through and no more, such Sprouts melt in the mouth like the cenderest Cauliflower, and are equally as good.

IMPROVED HALF DWARF-The very best and surest strains.

IMPROVED DWARF-Compact heads of fine quality.

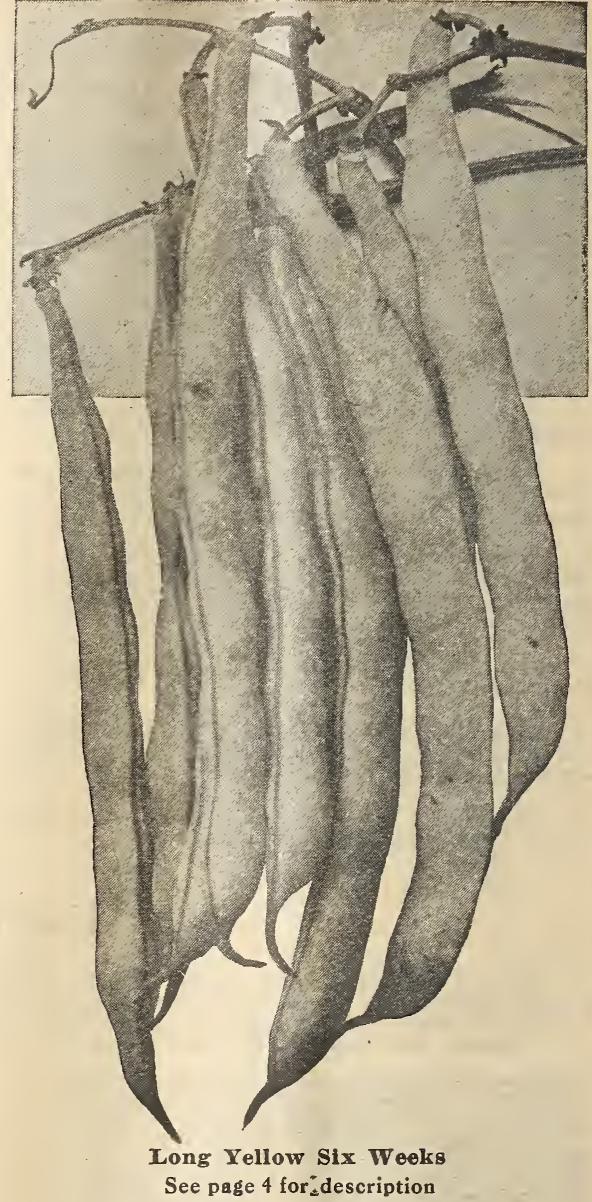

\section{CHERVIL}

CULTURE-Cultivate and use the curled variety of Chervil like Parsley. Sow at any time in the spring, in shallow drills, one foot apart, in well-prepared ground. The seed of the Tuberous Chervil should be sown in August or September, and treated like the Carrot.

CURLED-The leaves of this are used for flavoring soups and stews and for garnishing, same as Parsley.

\section{CHICORY}

Chicory is cultivated chiefly for its roots, which are dried and used as a substitute or flavoring ingredient for coffee. The leaves, when blanched, are also esteemed as a salad. Cultivate as recommended for Carrots.

LONG ROOTED MADGEBURG-Roots are the Chicory. 


\section{Cabbage}

Ready for Use in 75 to 210 Days.

WVE CARRY THE FINEST S'TRAINS OF ANEIRICAN LONG ISLAND GIRONVN CABBAGE SEED. MARKET GARDENERS CAN DLPLND ON PLAN'TS FIOM OUR SLED HEADING.

CULTURE-Soil for Cabbage should be a rich and heavy loanl, with good drainage. In a month the plants will be in condition to transplant to cold frames, where they are wintered, taking care, in planting, to set the young plants down to.the first leaves. Transplant in spring as soon as the ground can be worked, setting the plants two feet apart one way and from twelve to fifteen inches the other, according to the variety. For late or winter crops the seed is sown in May, and the plants set out in July. In this case they are set in rows 2 by 3 feet, so as to work them with a horse and cultivator. To destroy the green worm that is so destructive to the leaves and heads of Cabbage and Cauliflower, an experienced grower says: "Take one ounce of saltpetre and dissolve it in twelve quarts of water, then take a short-handled whisk broom, dip it in the solution and sprinkle the plants well. One application is sufficient unless the stuff is washed off by heavy rains. The liquid being perfectly clear, never colors the Cauliflower or Cabbage heads. To prevent the turnip flea from attacking the young plants, sift fine air-slaked lime or tobacco dust over them as soon as they appear above the ground.

ALL HEAD-The very best secondearly, fine flat heads, very hard, solid.

COPENHAGEN MARKET-Good solid heads, very early.

EARLY JERSEY W A K E F I E L DWell known and most valuable for early.

EARLY WINNINGSTADT-A standard second-early variety; pointed heads.

EARLY DWARF SAVOY-The earliest Savoy variety; distinct and good.

EARLY FLAT DUTCH-A remarkably fine strain; a sure header; the head weighing from ten to twelve pounds, most valuable for market.

ETAMPES-A fine extra early small French sort, with pointed heads; very solid.

EXPRESS-The earliest of all; small, solid heads; fine quality; fine for forcing.

GENUINE SURE-HEAD-Never fails to make a large, fine head, with few outer leaves; fine grower: flat Drumhead.

HENDERSON'S EARLY SUMMER-A superior second-early sort, produces large and solid heads of fine quality.

HENDERSON SUCCESSION-An excellent second early or late sort on the style of All Seasons.

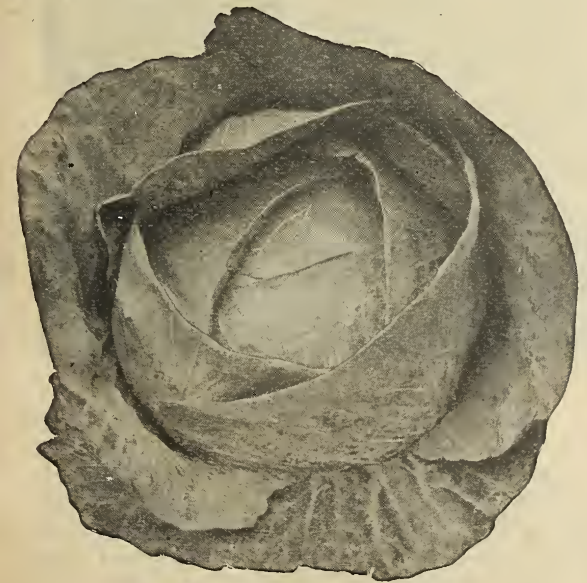

Premium Late Flat Dutch

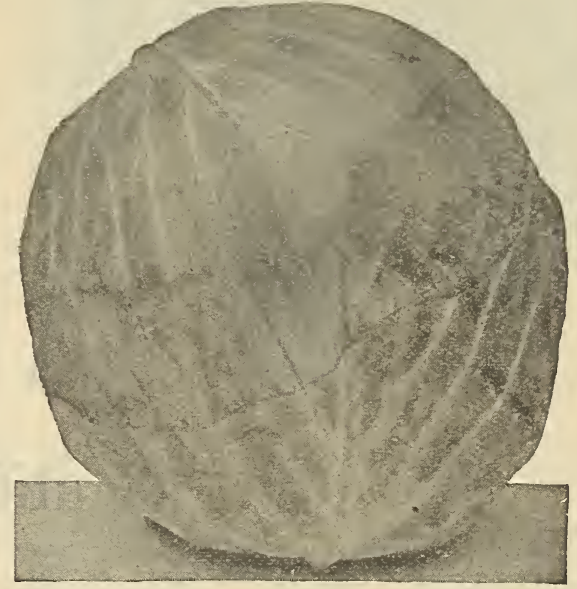

Copenhagen Market.

HOLLANDER-One of the hardiest in eultivation; quite a distinct variety; medium size, round, very solid, extra keeper, best of quality-our seed is from a very reliable Danish grower.

MAM. ROCK RED-Very large, solid, red heads, the finest strain of red.

MARBLEHEAD MAMMOTH DRUMHEAD-The largest Cabbage $\mathrm{know} n$, weighing in some instances over fifty pounds; under good cultivation acres have been grown where the heads would average thirty pounds each.

PREMIUM LATE FLAT DUTCHAlso a valuable main crop.

IRED DUTCH-For pickling; hard, oblong heads; dark purple.

SELECTED ALI SEASONS-One of the finest for second-early or late, growing to a large size, quickly and surely; the true sure header.

STONEMASON DRUMHEAD-A standard winter cabbage for main crop.

ST. LOUIS LATE MARIKET GARDEN -A very fine late first cabbage; a very sure header, especially fine for Southern trade. 


\section{Garden Carrots}

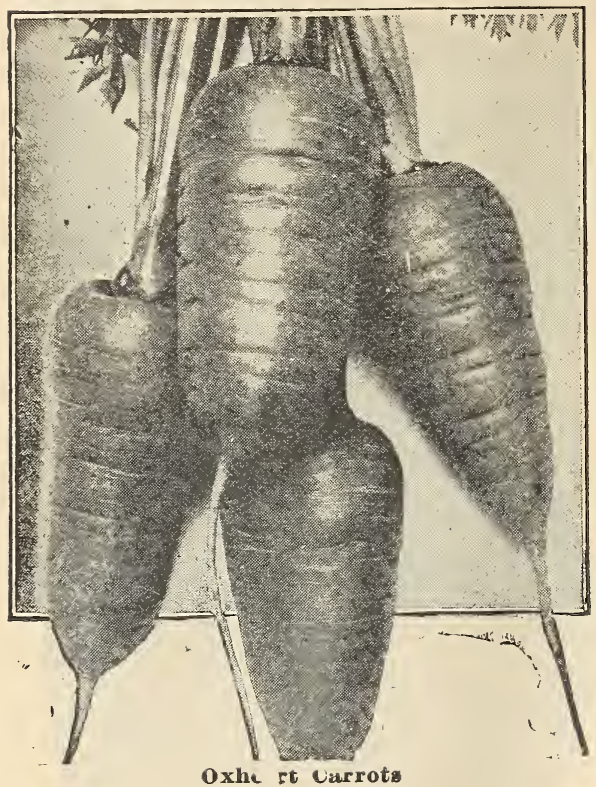

Ready for Table in 60 to 80 Days.

EARLY HORN-Very early variety, small root; excellent flavor.

FRENCH EARLY FORCING-Tender and fine; best for early and late crops and frames.

HALF-LONG STUMP ROOTED, CHAN TENAY STRAIN-Style of Nantes; has broader shoulder.

HALF-LONG STUMP ROOTED CARENTAN-Coreless; flesh red, of fine quality.

HALF-LONG DANVERS-Thick, of good quality and exceedingly productive.

LARGE WHITE B ELG I A N-Very large; excellent stock Carrot.

LARGE YELLOW BELGIAN-V e $r$ y large; excellent stock Carrot.

OXHEART OR HALF-LONG GUERANDE-This is one of the most valuable of recent introduction, either for family or market; most beautiful shape and rich orange color.

SAINT VALLERY-Very choice, grod flavored.

\section{Cauliflower}

CULTURE-This is the same as for Cabbage, except that extra manure and plenty of water will pay upon this. If the soil be dry, water frequently, and if the plants could have a heavy mulch of hay or straw, it would keep the soil moist and the plants would not suffer from drouth. The early kinds should be strong enough to plant out not later than the middle of April; the late kinds may be planted out same time as for Cabbage. To destroy the Cauliflower maggot, it is recommended to take one ounce of sulphuret of potassium and dissolve it in one gallon of water. Heat the liquid to about 100 degrees, take a large spoon, or something that will hold the 100 th. part of a gallon, and pour the liquid against the stalk of the plant just above the ground.

EXTRA EARLY DWARF EREURTShort stem; very fine.

LARGE EARLY DWARF ERFURTFinest strain.

HALF EARLY PARIS OR NONPAREIL-Popular early white.

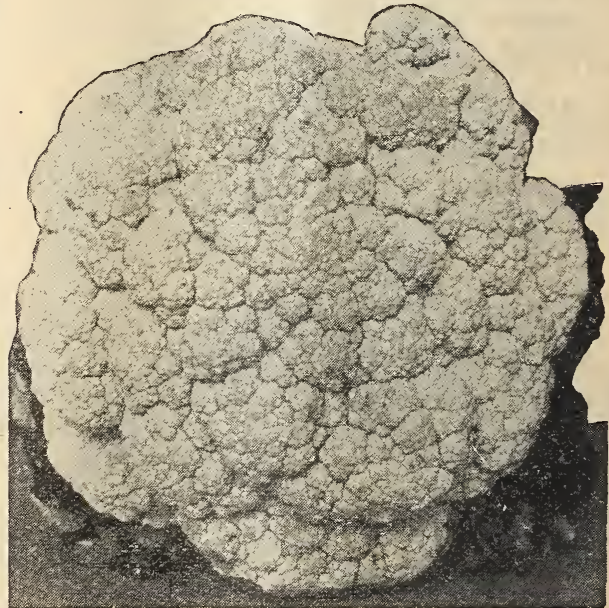

Henderson's Early Snowball Ready for Use in 90 to 120 Days.

HENDERSON'S EARLY SNOWBALL -Without doubt the best of Caullflowers: our seed is of the very finest strain: grown specially for us in Denmark, and sure to make a fine solid head; don't buy cheap Cauliflower seed; there is no seed in which quality counts so much. 


\section{Celery}

CULTURE-Sow the seed in a light, rich, dry border as early as the ground can be worked, in drills eight or ten inches apart, and cover the seeds about a quarter of an inch deep, rolling or treading them in if the ground be dry. When fairly out of the seed leaf they may be transplanted to another bed, or they may be thinned out in beds or trenches. The bed should be kept well weeded, and an occasional soaking with water in dry weather will do the plants good. Early in July at the north, a month or six weeks later in the southern states, is the proper time to set the plants out in beds or trenches. Press the soil firmly against the roots. In the garden the botter way is to set the plants in shallow trenches-we say shallow, for it is obviously a bad plan to remove all the good soll (as must be done in a deep trench) and put the plants in that which is poor. The plants may be set in a single row in a narrow trench, or the trench may be made into a bed wide enough to hold two, three or four rows, and in case the plants are in a compact form, to be covered for the winter where they grow.

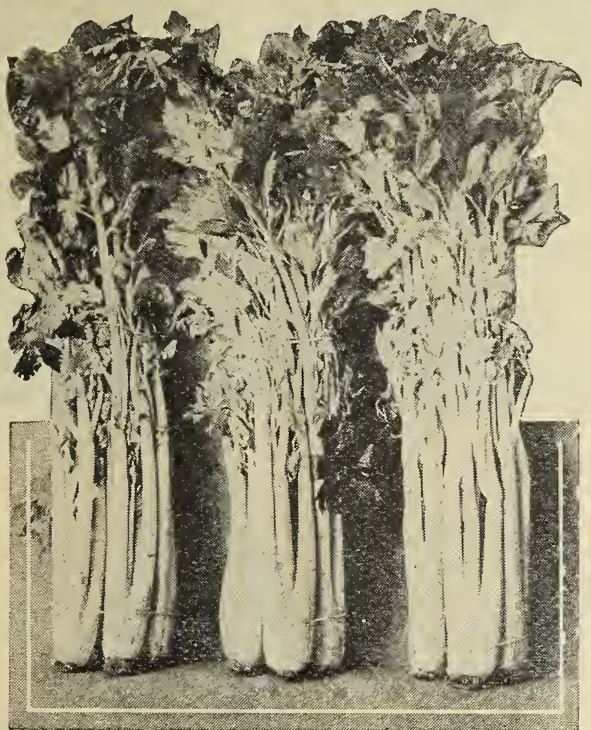

Giant Pascal

IMPROVED WHITE PLUME-Naturally white or light foliage; requires but little banking up to blanch; very early and extensively grown for market.

GOLDEN SELF-B I A N C H I N G-A grand solid variety, on the style of the White Plume, except that it is golden yellow where the Plume is white.

GIANT PASCAL-An easily blanched and fine keeping large sort, of excellent flavor; superior for late use.

PINK PLUME-A strong, healthy, compact grower, with no tendency to rust; very solid, crisp, extra early and a long keeper.

GIANT WHITE SOLID-Large, round, crisp and solid; the old well-known variety.

CELERIAC OR LARGE SM O OTH $P R A G U E-A n$ improved form of the rooted celery, roots smooth and round.

GOLDEN HEART DWARF-A very popular and distinct variety; in habit of growth it resembles the Half Dwarf white sorts, except that when blanched, the heart, which is large and full, is of a waxy golden yellow.

\section{CELERY FOR FLAVOA}

\section{CORN SALAD, or Fetticus}

CULTURE-Sow during August or early in September, in drills a quarter of an inch deep and six inches apart. If the weather is dry when the seed is sown, tread it in slightly to insure germination. Keep down weeds with hoe. Just before winter cover thinly with straw or leaves:

LARGE SEEDED-The best variety for family use; makes delicious salad; used during the winter as substitute for Lettuce.

\section{COLLARDS}

CULTURE-Sow seed as for Cabbage in June, July and August for succession; transplant when one month old in rows a foot apart each way and hoe often. GEORGIA GROWN OR SOUTHERN-

\section{CRESS}

CULTURE-Sow thickly in shallow drills every two or three weeks. It is useful not only for salad, but for the breakfast table and for garnishing. Water Cress should be sown in damp soil, or if a stream of water can be utilized, it would be much finer. It will also thrive in damp hot-beds. Rightly managed its culture is very profitable. To obtain early salad, it is a good plan to sow with the Water Cress seed a strip four inches wide on the outer margin of a hot-bed, inside the frame (where it is always cool). This will be found a satisfactory method of obtaining it early.

\section{CURLED OR PEPPER GRASS}

\section{BROAD LEAVED.}

BROAD LEAVED WINTER

TRUE WATER CRESS 


\section{Sweet Corn}

Plant as soon as the ground becomes warm in the spring, in hills about three feet apart; give thorough cultivation. Our sweet corn is carefully grown and selected, only the choicest, most perfect ears being selected for seed. It is far superior to ordinary stock. We pay postage by the packet or pound.

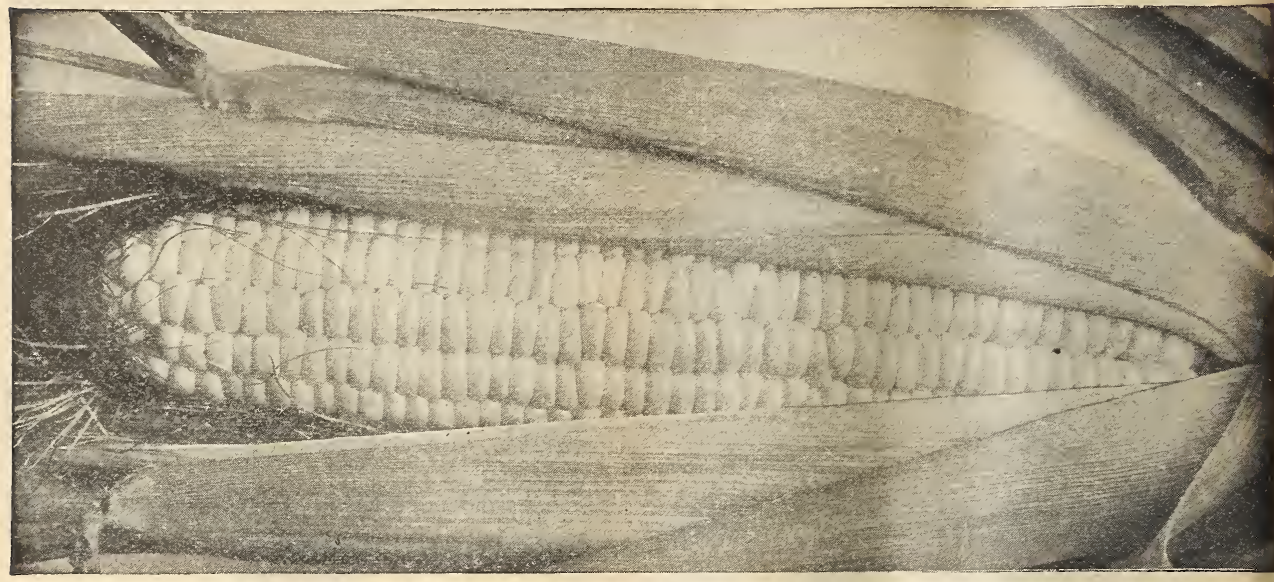

Golden Bantam

\section{Early Varieties \\ From 55 to 65 Days}

GOLDEN BANTAM-Of extreme hardiness; can be planted earlier than any other true sweet corn and will then produce the earliest supply of ears for the table. Extra fine in quality.

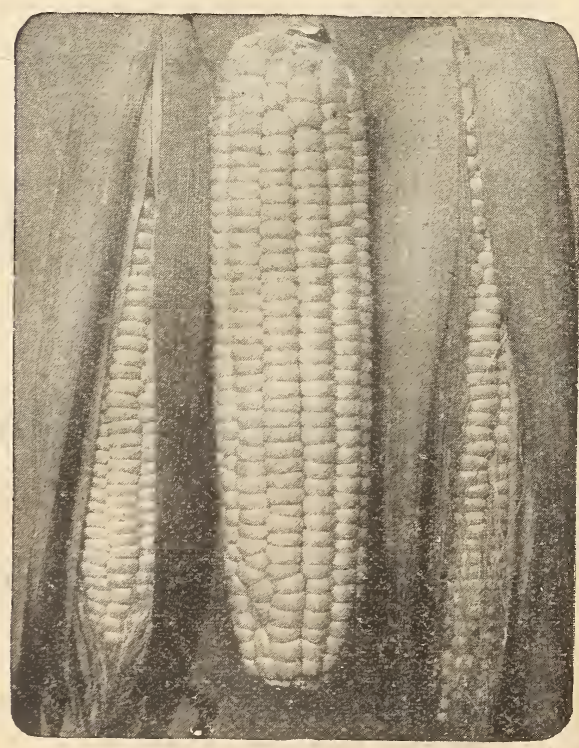

Early Minnesota

PEEP OF DAY-This most valuable sort is of Minnesota origin, and is not only early, but one of the best. The stalks grow from 3 to 4 feet high. Ears average from 5 to 6 inches in length and are of perfect form.

EARLY CORY, RED COB-A new early variety, with good sized ears and large grains; excellent for market.

WHITE COB CORY-Resembles the ordinary Cory in size and earliness, but with white cobs; very much better quality.

MAMMOTH WHITE CORY-Largest extra early corn known; fine quality, 12rowed compact ears.

MARBLEHEAD-One of the earliest; तwarf, with short, thick ears; of good cuality for an early sort.

GARLY MINNESOTA. This is one of the oldest and most popular of the early sorts, both for the market and private garden. Stalks about five feet high, with no suckers and bearing two ears well covered with husks. Ears long and eight rowed. Grains very broad, sweet and tender and shrinks but little in drying. Our stock is very uniform in quality. 
BLACK MEXICAN-Very sweet and of superior flavor; grains black.

EARLY CROSBY-Matures after the Minnesota; fair sized ears of good quality.

EARLY ADAMS-Not a sugar corn, but grown extensively all over the country for market purposes.
EARLY EVERGREEN-By careful selection for a series of years we have producen an early strain of this corn, earlier by ( 08 days.

EARLY CHAMPION-A new and very desirable sort; ears nearly as large as Evergreen; pure white; only a few days later than Minnesota; very fine for market gardeners.

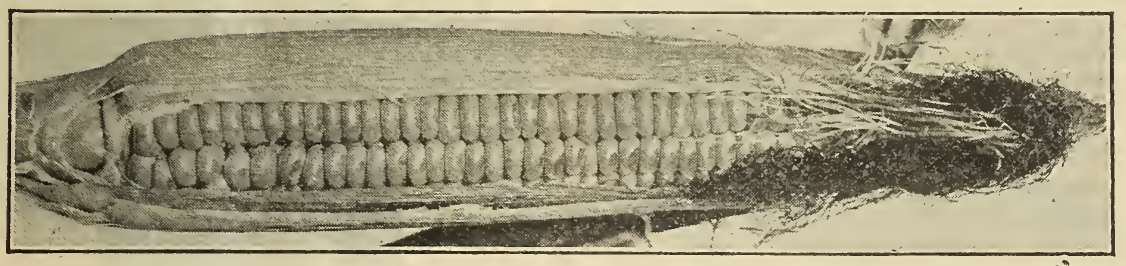

Stowell's Evergreen

\section{General Crop or Late Varieties}

COUNTRY GENTLEMAN-Same as Ne Plus Ultra, but with large ears of delicious quality.

IMPROVED WHITE EVERGREEN.The cobs and kernels are at all stages of edibility beautifully white. The getting rid of the ember tint so crominent in a great many strains of sweet corn passing for Stowell's Evergreen is a great gain, as it fits this variety for extensive use in canneries.
NE PLUS ULTRA-Small, but one of the sweetest sorts grown.

OLD COLONY - A very good late variety of very rich, sweet flavor; ears bear 16 to 20 rows of kernels, and are very heavy and solid.

STOWELL EVERGREEN-Remains a long time, and is highly prized; one cf the most popular varieties.

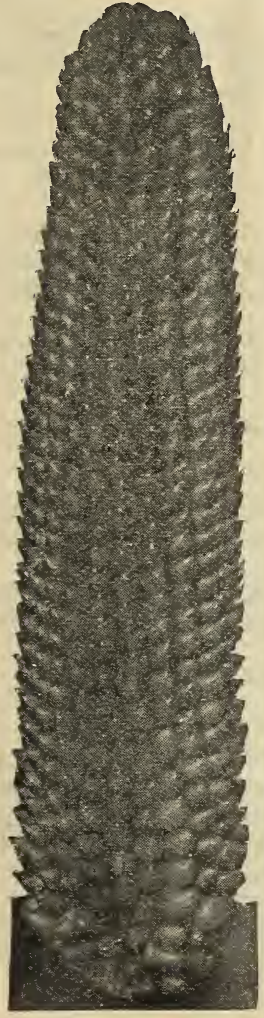

\section{Pop Corn.}

Pop Corn can be grown to advantage in a commervial way and no farm or garden is complete without a few rows of this delicious confection, for who does not recall with pleasure bleak winter evenings enlivened by a dish of pop corn. In parts of Iowa they are growing pop corn almost exclusively as a free crop and are receiving better prices for it each year. It can be planted at least twice as thick as other varieties of corn and it matures very early. Very often there is good money in little things, which, because they are small, people are apt to overlook. Pop corn is one of these.

There are several varieties but the following varieties have done the best for us in the past.

WHITE RICE. This variety of pop corn is an old and tried corn. It is the heaviest yielder of all and of very good quality. The stalks grow from 5 to 6 feet tall and produce two to three ears each. The ears are about 6 inches long and covered from butt to tip with long, hard, flinty kernels. When popped the kernels are very large and tender. We recommend this variety especially for its large yielding ability and its popping qualities. Besides this it will yield from 8 to 10 tons of good fodder.

\begin{abstract}
A U S T R A I A N HULL-LESS OR JAPANESE. This is a very heavy yielder of attractive ears peculiar in form, being nearly as thick as it is long. The crowning merit lies in its popping qualities. It is a quick popper, fine flavor, absent of hull or shell, being soft and tender and of delicious flavor. Try a package of this for
\end{abstract}

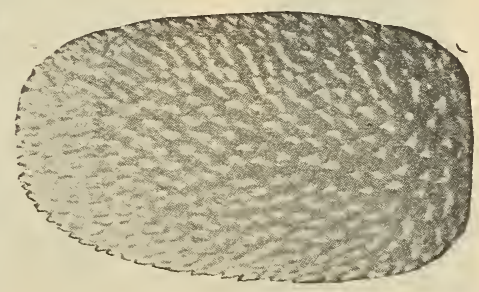

White Rice home use. 


\section{Cucumbers}

ARLINGTON WHITE SPINE-A selection from the White Spine, being more pointed at each end; the young fruits are usually crisp and tender and are of very dark grien color, so that the variety is considered by name to be the best for small pickles.

BOSTON PICKLING-A favorite eastern sort of fine quality.

CHICAGO PICKLING-Very popular in Chicago market. Color deep green, medium size, prominent spines.

COOL AND CRISP-Straight, long, slim, dark green, fine for pickling.

EARLY CYCLONE-A short variety. The earliest by two weeks of any cucumber in cultivation; holds its color well and is very prolific, growing its fruit in bunches of three and fours and sometimes producing 10 to 12 specimens to the plant.

EARLY GREEN CLUSTER-Fru 1 t small and in clusters; very prolific.

EARLY RUSSIAN-Very early, short, is a valuable variety for small pickles, for which it is often much in demand.

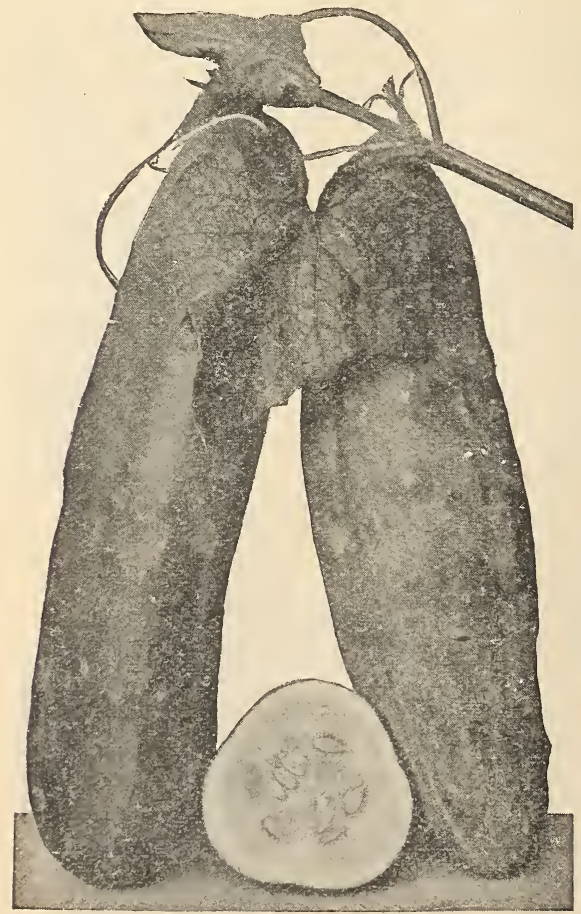

The Davis Perfect Cucumber
EARLY SHORT GREEN (or Early Frame)-Good for pickling; productive.

EARLY WHITE SPINE-Early, and good for pickling or table use.

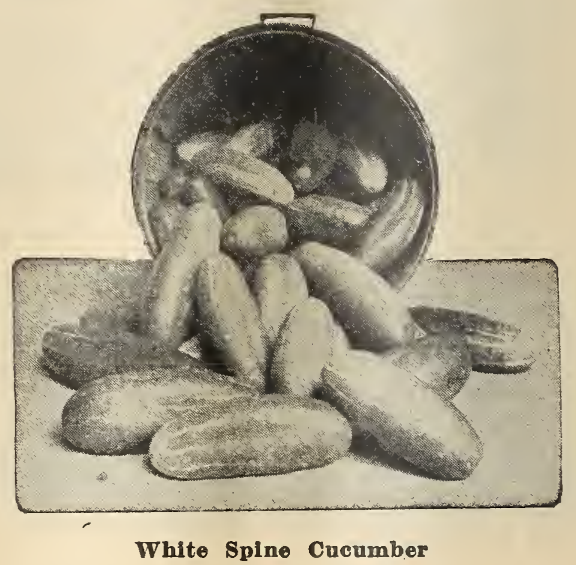

EVERGREEN-Very early and prolific; retains its fine deep green color in all stages of growth.

FORDHOOK FAMOUS-Long, straight, vigorous grower; very productive.

GREEN PROLIFIC PICKLING-One of the best for pickling, dark green, very productive and of uniform small size.

IMPROVED WHITE SPINE-W E 11 flavored and of medium size.

JAPAN CLIMBING-Can be grown on trellis.

JERSEY PICKLING-Medium length, skin thin, pure white.

LONG GREEN-Long and crisp, a popular and rellable variety for pickles.

SMALL GHERKIN-Very small burr, used for pickles.

THE DAVIS PERFECT CUCUMBERAn excellent cucumber for both outdoor use and forcing. It is a carefully selected strain of the extra long White Spine type made by a veteran outdoor and greenhouse grower of cucumbers. Its valuable points are length, slimness and its dark green color. It is a very vigorous sort and resists blight longer than most long sorts. 


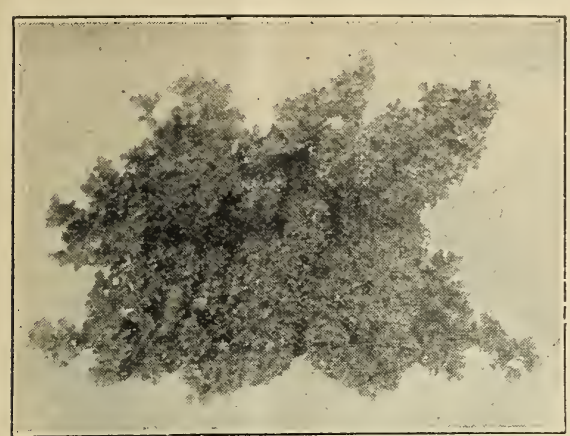

Kale, Moss Curled.

\section{EGG PLANT}

CULTURE. Egg Plant seed should be sown in hot-beds in March or April and transferred to pots or boxes when an inch or two high and planted out early In June in rows $2 \frac{1}{2}$ feet apart each way, zultivation same as for cabbage.

BLACK BEAUTY-Fruit broad and thick, rich deep black, spineless, very early.

EARLY LONG PURPLE-Of distinct shade and fine quality.

IMPROVED NEW YORK PURPLEThe best large oval, deep purple, grown more extensively than any other sort.

ROUND PURPLE- $M$ e $d \mathrm{i} \mathrm{m}$, pear shaped, pale purple, good.

\section{ENDIVE}

This plant furnishes an attractive and appetizing salad for the fall and winter months, or by repeated sowing a supply may be had nearly all the year round.

BROAD LEAVED-A sweet variety, fall and winter.

GREEN CURLED WINTER-Standard sort for fall and winter crop.

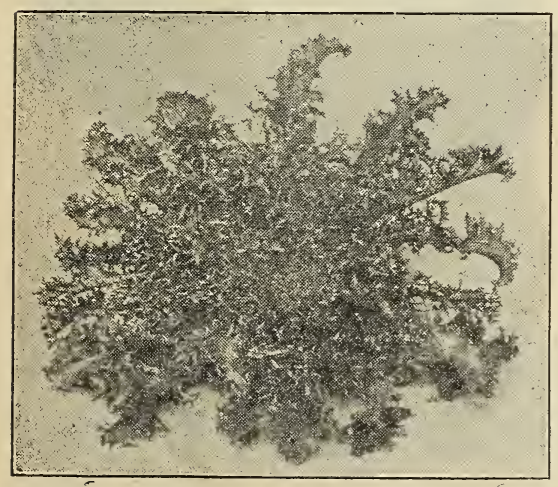

Endive

\section{USEFUL GOURDS}

NEST-EGG-Resemble in color, form and size the eggs of hens; do not crack, and are uninjured by cold or wet. They make the very best nest eggs. Do not plant in very rich soll, or the fruits will grow too larg.

DISHCLO'TH OR LUFFA-A natural dishcloth, and a most admirable one, is furnished by the peculiar lining of this fruit, which is sponge-like and durable.

DIPPER - When grown on the ground the stems will be curved; as a climbing vine the welght of the blossom end will cause the stem to grow straight.

\section{KALE, or Borecole}

CULTURE. More hardy than cabbage and makes excellent greens. Improved by a touch of frost. Sow in May ana June, cultivate same as cabbage.

CURLED TALL GREEN SCOTCH-A taller growth of the above; late variety. SIBERIAN-A fine dwarf variety.

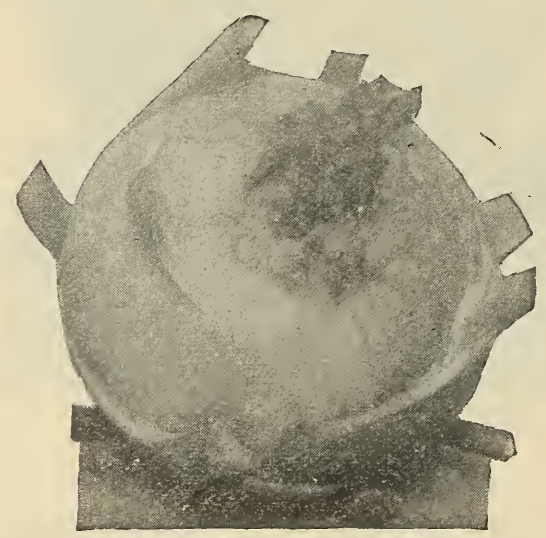

Kohlrabi, Early Whito Vienna.

\section{KOHLRABI}

CULTURE. Sow the seed in the spring in drills three-fourths of an inch deep and 2 feet apart and when the plants are a few inches high thin to 15 inches. Cultivate same as beets.

EARLY WHITE VIENNA-Handsome and delicate, white ball. sort.

EARLY PURPLE VIENNA-Very good

\section{LEEK}

CULTURE. Sow seed in early spring in rows 1 foot apart and 1 inch deep. When 6 inches high, transplant 4 to 6 inches apart in rows 12 inches apart, setting plants in the ground up to their center leaves and as they grow draw the soil up around them.

BEST LARGE FLAG WINTER-Hardy and productlve.

MUSSELBURG-Large standard sort; remains long in good condition. 


\section{Lettuce}

CULTURE. Sow in the house or in frames any time after March 1.0th; if put outdoors, as early in the spring as ground can be worked and at intervals of two weeks till June 1st. Soil should be a rich, sandy loam with plenty of humus. Rows to be $11 / 2$ feet apart, plants two inches apart in row after thinning. Two ounces of seed will sow 150 feet of row, 4 to 5 pounds required per acre.

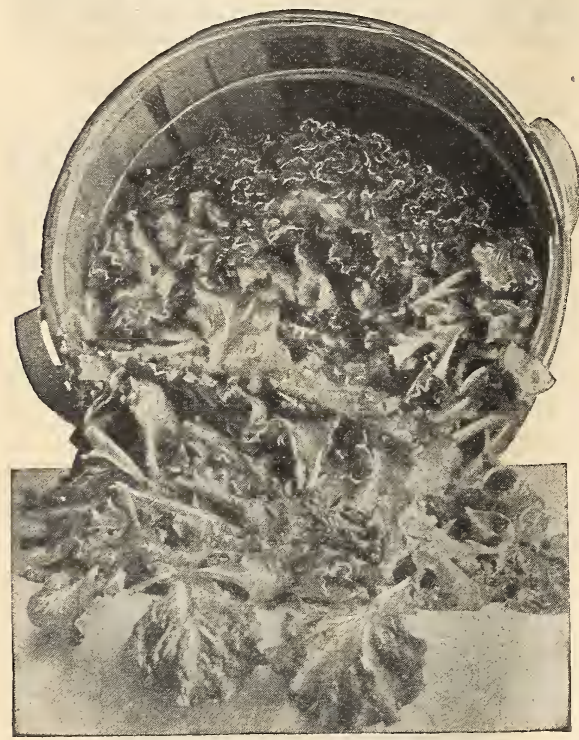

Black Seeded Simpson

Ready for Use in 40 to 60 Days.

BIG BOSTON-The best large heading early variety. Most popular variety for the southern gardener who ships north. Also very valuable as first early in the North. Plants are large, vigorous; leaves bright, light green, very tender. Our strain is unsurpassed. Many gardeners in the South will plant only Vaughan's Big Boston.

BLACK SEEDED SIMPSON-A SUperior variety; large and of light color.

CALIFORNIA CREAM B U TTE TRRound, solid heads, medium green, good size, compact, rich buttery taste.

DEACON-A large, solid cabbage-lettuce for summer.

DENVER MARKET-An early variety for forcing on open ground; large, solid head; leaves beautifully marked and blistered; very crisp.

EARLY CURLED SILESIA-An early, erect growing, clustering variety, which may be sown very thick and cut while the plants are very young, at which time they are exceedingly tender, sweet and well flavored; color light green.

EARLY OURLED SIMPSON-A leadIng early sort; very tender.

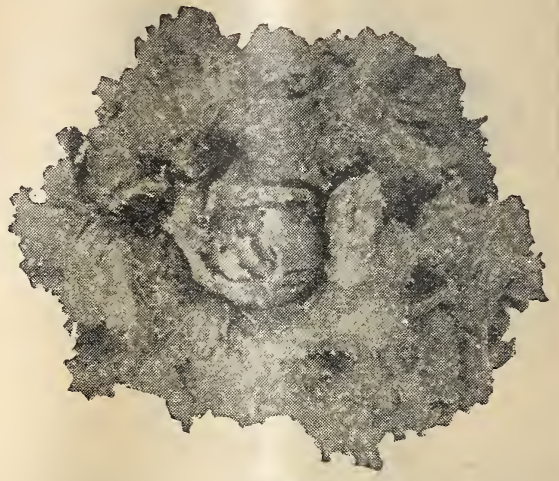

Iceberg

EARLY PRIZE HEAD-Bright green, tinged, with brownish red, tender, crisp.

GRAND RAPIDS FORCING-Large, tender heads, one of the best for early forcing.

ICEBERG-Fine compact heads which resist summer heat admirably; is very popular; leaves curled and light green; crisp, tender.

IMPROVED HANSON-Very large and solid, sweet, crisp and tender.

PARIS WHITE COS-Fine if sown very early; requires tying up to blanch.

TENNISBALL WHITE SEED-A wellknown forcing variety.

TENNISHALL BLACK SEED-Forms close, hard heads; good for forcing.

WHITE SUMMER CABBAGE-Close heads of good size; fine for summer.

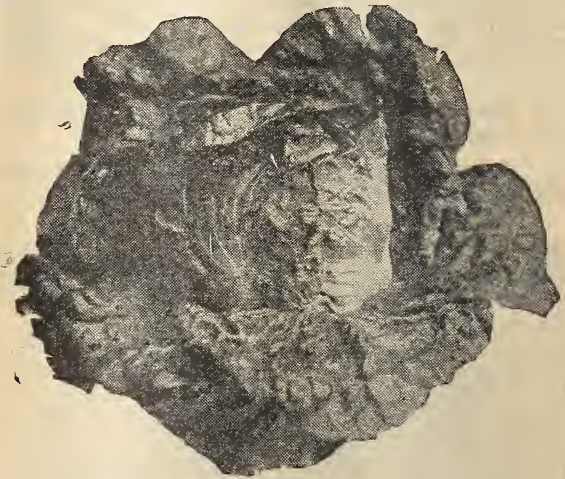

Big Boston Lettuce

\section{Mustard.}

It is Cultivated for Salads and Greens. WHITE. Best for salads.

BROWN or BLACK. More pungent in flavor than the white.

SOUTHERN GIANT CURLED. Leaves twice the size of the ordinary White Mustard. 


\section{Musk Melons}

CULTURE. Muskmelons delight in moderately rich, warm, mellow loam. The seed should be planted in the spring upon the arrival of settled warm weather. Plant seeds 1 inch deep in hills, 4 to 6 feet apart each way, and as soon as the plants begin to run, remove all but 4 of the most likely ones.

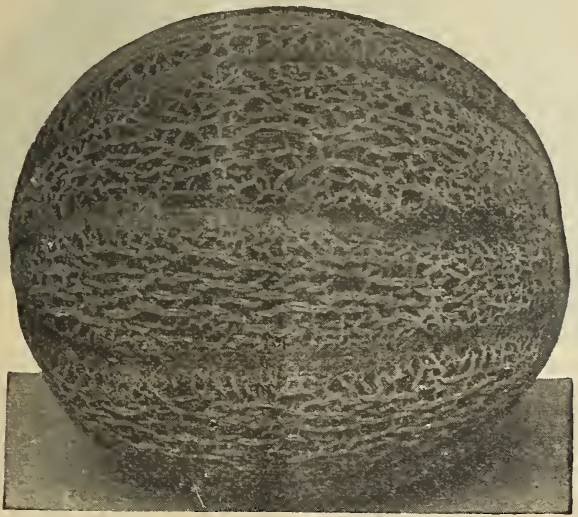

Salmon Fleshed Rocky Ford.

BALTIMORE MARKET-Oblong; orange flesh, fine quality.

BANANA-Cucumber shaped, highly perfumed, of indifferent quality; late.

BAY VIEW-Very proliflc and of great size; oblong; green flesh, late.

BURRELL'S GEM-N e w $S$ a $1 \mathrm{mo}$ Fleshed Musk Melon-Grown in a comparatively cool location or at a considerable elevation, the Burrell Gem comes close to perfection, having fruits of good size, handsome appearance, and of fine flavor, but when grown in light, warm soils the melons come with softer flesh and are liable to split or crack open at the blossom end. The melons are six to seven inches long by four and a half to five inches in diameter, rather sharply sloping at the ends. They are quite well ribbed and covered with a fine grayish netting. The skin is a rich dark green, contrasting finely with the deep orangesalmon colored flesh, sweet and tender. The flesh is thick and firm, ripening close to the skin, leaving only a thin rind.

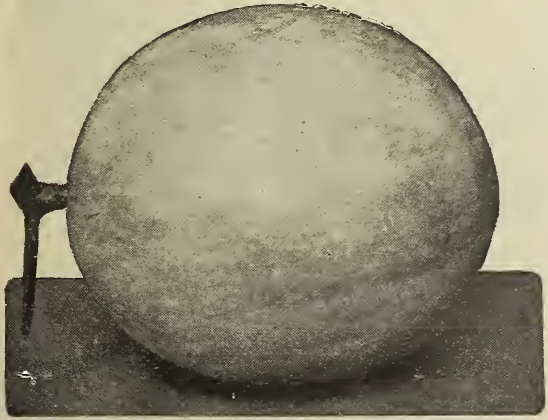

Halbert Honey

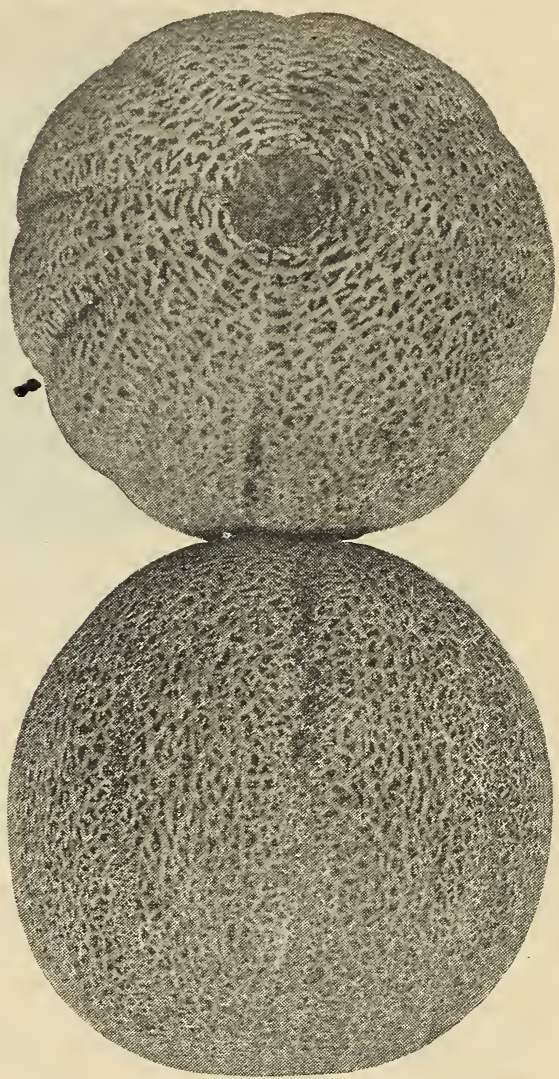

Extra Early Hackensack

EXTRA EARLY HACKENSACK-Ripens ten days earlier than the Hackensack.

EMERALD GEM-Small, extra early; smooth ribbed, dark green skin and orange flesh; quality first rate, very sweet.

GOLDEN NETTED GEM-Very early; is small and of fine flavor; green flesh.

GREEN NUTMEG-Named from its shape, green flesh, good for main crop.

LATE HACKENSACK-Large, round, and of good quality; a popular variety.

NETTED BEAUTY-Extra e a r ly; densely netted; flesh pale green.

OSAGE-Cocoanut shaped, y e llow flesh, light green, netted skin; good quality, intermediate.

PRINCESS-Salmon fleshed, very distinct, nearly round, dark green, netted, sweet and luscious.

ROCKY FORD-This is the most popular of the basket melong; oval, light ribbed, densely covered with coarse green netting, flesh thick, green and sweet. highly flavored. 


\section{Water Melons}

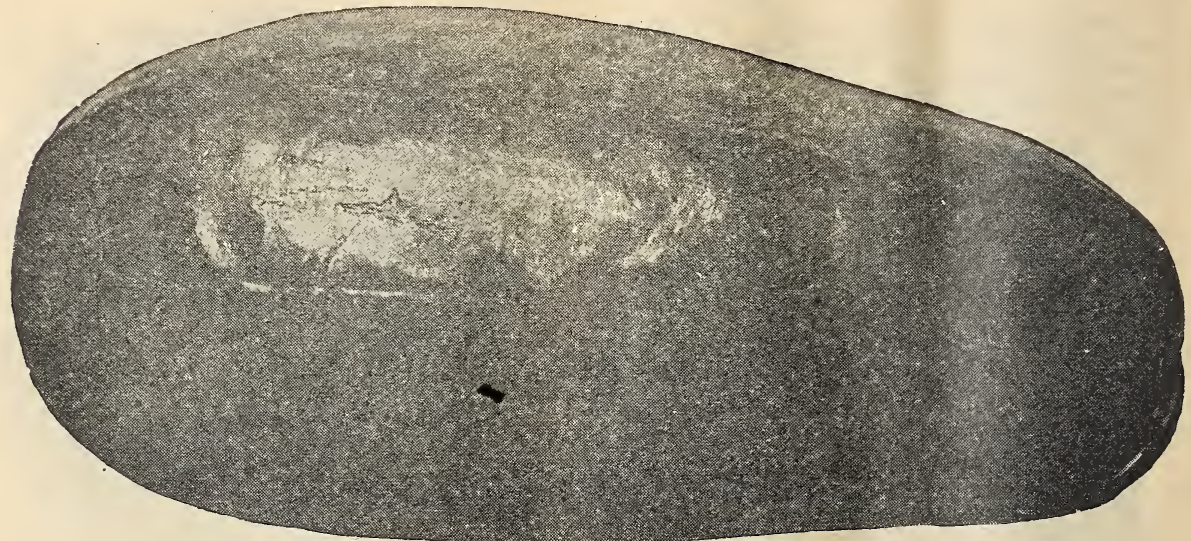

\section{Halbert Honey}

CULTURF. The soil for Watermelons must be light, rich and sandy, for if grown on a heavy soil the quality will be poor, and they will not be so early. When there is no more danger of erost, drop 8 to 10 seeds in a hill 8 to 10 reet apart each way, covering about $3 / 4$ inch deep. As soon as plants commence to run, thin out to 3 best plants in a hill and cultivate until the vines cover the whole ground. If slow to fruit, pinch off the ends of the growing shoots. Ashes or air-slacked lime sifted on the young plants while dew is on is good to keep the insects out. One ounce will plant about 130 hills, and it takes 4 to. 5 pounds to one acre.

Ready for Use in 60 to 90 Days.

COLE'S EARLY-Very early, very sweet; fine home melon.

CUBAN QUEEN-Solid and heavy, skin marked regularly; excellent quality; early.

PEERLES OR ICE CREAM-Very early; red flesh, good home melon.

SEMINOLE-Very large; quality first rate; intermediate.

ICEBERG (BLUE GEM)Large, thick, oval form, rich dark green, fine shipper.

HUNGARIAN HONEY-A very early sort from Hungary; fine for northern latitudes; perfectly round, flesh brilliant red, seeds very small.

KENTUCKY WONDEROblong, dark green skin, scarlet flesh.

KLECKLEY'S SWEET OR MONTE CHRISTO-O b 1 o $\mathrm{n} \mathrm{g}$, rich dark green, flesh bright scarlet; very sweet.

JONES, J U M B O - Very large, fine green color, meat deep red, flne shipper.

KOUB GEM-Large, bright red flesh, of fine quality and a g o od shipper, intermediate.
DIXIE-A new melon of excellent quality; very large and solid, flesh red; intermediate.

FORDHOOK EARLY-An extra early, of extra fine flavor, and large size; color a uniform green; average weight from 30 to 40 pounds.

GEORGIA RATTLESNAKE-Oblong, dark and striped; bright red flesh; late.

HALBERT HONEY-Brought out by Burpee a couple of years ago as the sweetest of all melons, and I am inclined to believe that he is right about it. They are much like Kleckley, but longer in shape; dark green, very sweet and very tender. Break easily in handling. Large size and fine for home use or nearby market. flavor.

GOLDEN HONEY-Yellow meated, flne

MOUNTAIN SWEET-Large oval variety, green rind, flesh scarlet, sweet and delicious; fine for home garden.

SWEETHEART-One of the best early shipping melons; fruit large, oval, mottled, light green, flesh bright red, firm, melting and sweet.

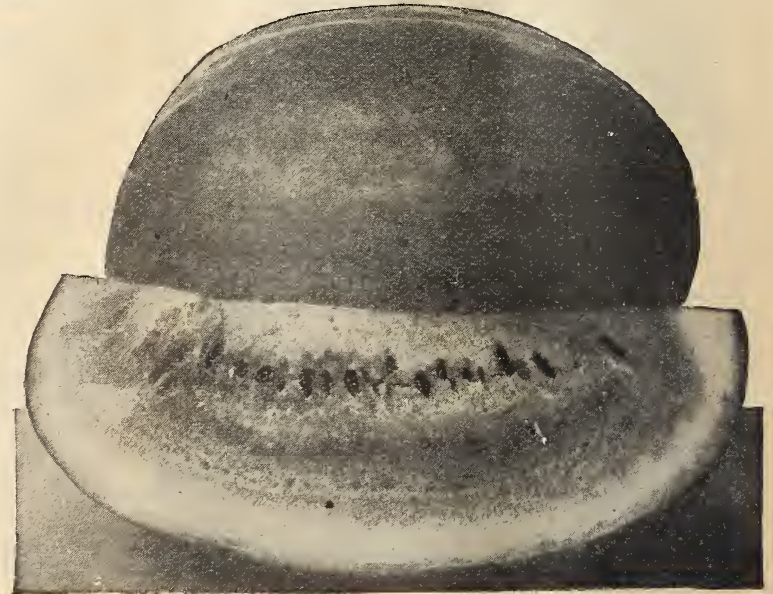

Cuban Queen 


\section{Onion Seed}

CULTURE. Soil for Onions should be rich in humus and plant food. Fresh stable manure and barnyard litters are entirely out of place on the Onion field. They are usually loaded with weed seeds and will interfere very much with tillage. Compost heaps will destroy the weed seeds and put the manures in such condition that they will readily mix the soil. Manure from sheep sheds or pig peris applied with a spreader before the ground is plowed in the Fall makes excellent fertilizer for Onions because it is usually comparatively free from litter and foul seeds.

AUSTRALIAN BROWN, the Great Set onion-A grand new onion from Australia. This is a truly remarkable variety, remarkable in three ways: 1st, they ripen extremely early; $2 d$, they keep almost indefinitely, much longer than wil any other onion; $3 \mathrm{~d}$, they never make any thick necks or scullions.

EARLY RED FLAT-Color of Wethersfield, early.

EARLY RED GLOBE-Fine onion, mild and tender; not good keeper. white.

GIANT WHITE TRIPOLI-Very large

GLOBE WETHERSFIELD-Cross between Red Wethersfield and Large Red Globe; beautiful onion, fine keeper, fine for the market gardener.

LARGE RED WE'THERSFIELD-Half early and a good keeper; standard sort.

LARGE RED GLOBE-S o $u$ th port strain, one of the best reds, good keeper.

LARGE WHITE POR'TUGAL-Standard sort, flat.

LARGE W I T E GLOB E-Large Southport strain.

LARGE YELLOW GLOBE-Southport strain, large, flrm, mild, good keeper.

MAUL'S PRIZETAKER - Very large beautiful onion, white flesh, skin straw color; sweet, mild, tender; keeps medium.

NEW QUEEN-Very early small white sort, the best for pickling.
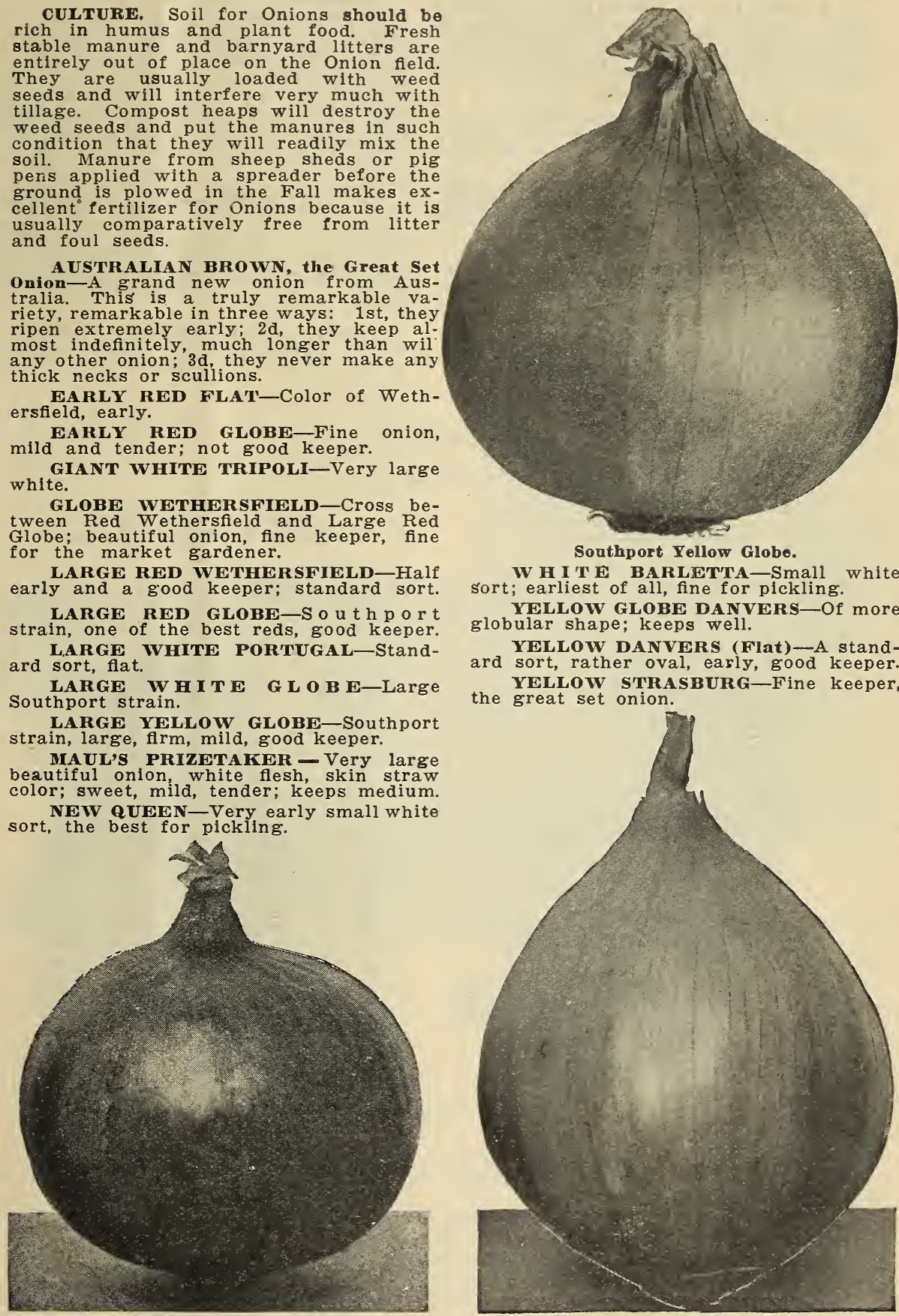

Southport Yellow Globe.

W H I T E BARLETTA-Small white sort; earliest of all, fine for pickling.

YELLOW GLOBE DANVERS-Of more globular shape; keeps well.

YELLOW DANVERS (Flat)-A standard sort, rather oval, early, good keeper. YELLOW STRASBURG-Fine keeper, the great set onion.

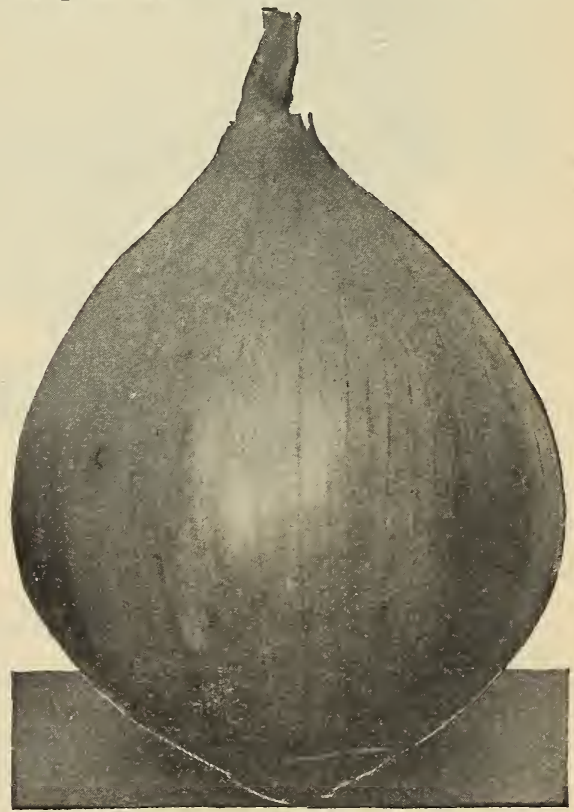




\section{Onions-Continued}

A USTRALIAN YELLOW GLO B EMost handsome globe onion with a brownish yellow skin and crisp, finegrained white flesh. They average from 2 to $21 / 2$ inches in diameter and ripen a little earlier than the Red Globe.

M A M M O TH SILVER KING-Very large, white skin and flesh, mild flavor, flat shape; frequently weigh 3 pounds.

NEW CRYSTAL WHITE (Tenerifie Seed)-Large, pure white, finest slicing onion for the home garden. True seed is very scarce.

RED BERMUDA (Tenerifie Seed)Similar to the white, but with red skin.

WHITE BERMUDA (Tenerife Seed) -The Bermudas are the earliest onions in the market, and are grown extensively in the South. Outer skin straw color, flesh pure white.

\section{Onion Sets.}

CULTURE. Soll requirements the same as for Onion seed. Place the onion sets 3 to 4 inches apart, according to size, 3 inches deep, in rows 1 foot apart. It is customary to furrow out the soil with a little hand plow early in the Spring, set the onions in this furrow right side up and cover with a garden rake and if the soil is dry it should be well firmed over the sets; 380 to 480 pounds of sets required for an acre.

RED TOP SETS. These are planted to produce both early green onions and large eating onions. We wish to call attention to the fact that our stock is the genuine Red Top Set, unmixed with Egyptian Winter Sets, which are always cheaper, but practically worthless for spring planting.

WHITE BOTTON SETS. These are small, solid, and of beautiful silvery white, a favorite sort in private and market garden.

\section{Onion Sets, Top; Etc.}

\section{PRICES ON APPLICATION}

\begin{abstract}
Yellow Onion Setr, Bottom Red Onion Sets, Bottom Yellow Potato Onions
\end{abstract}

White Potato Onions Top or Button Onions White Onion Sets, Bottom

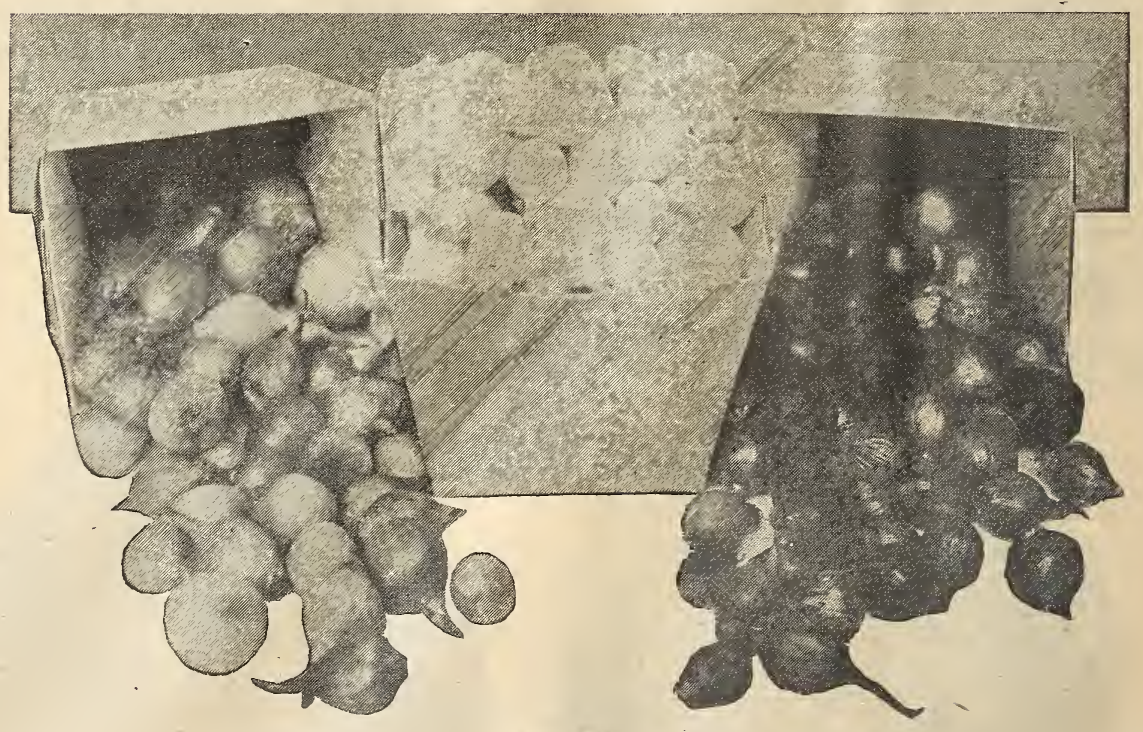

Onion Sets

\section{OKRA, or Gumbo}

CULTURE-Sow late in the spring, after the ground has become warm, in drills three feet apart, where the plants are to remain. Thin out from nine to twelve inches. They should be well manured. They may also be raised in pots or a hotbed and transplanted.
DWARE.

\section{LONG GREEN.}

EARLY DWARF .

WHITE VELVET-Long pods; fine flavor; very tender. 


\section{Peas}

Ready for the Table in 50 to 70 Days.

CULTURE-A week may be gained in earliness by sowing a quantity in moist sand, placed in a box in the cellar, planting outside when well sprouted. Light, dry soil, not over rich, suits the pea. Sow as early as the ground can be worked, and again every ten days, for succession, up to the first of June, after which there is danger from mildew. Sow in single or double rows, from four to six feet apart, according to the different heights, about an inch apart in rows (except such sorts as we note to sow thin) and four inches deep. Hoe often and keep the ground clean and fine. The tall sorts can be made to bear more freely by pinching-in. The dwarf varieties may be grown in beds like Bush Beans, with rows about the same distance apart. The holes which are sometimes found in peas are caused by the Pea Weevil (Bruchus pist). This insect is a native of this country, but, as usual with such pests, has spread rapidy and is now found nearly all over the world. The beetles lay their eggs on the young pods and the larvae, as soon as hatched, make their way through the pods into the nearest peas. They do not, as is sometimes supposed, destroy the germ, for peas will grow if they are infested, but the plant is likely to be more feeble, and for this reason will not produce as large a crop as if free from the weevil.

Peas marked thus (*) are wrinkled.

\section{Extra Early Peas Special Price on Quantity.}

*GRADUS-A new English variety of the wrinkled peas; it is very hardy, so much so that, unlike most of its type, it can be planted extremely early; the vine grows about $2 \frac{1}{2}$ feet high, is vigorous and very productive; the pods are large and well filled with good sized peas, seven to nine usually in a pod. The Gradus is the earliest wrinkled pea in cultivation and one of the most delicious in quality.

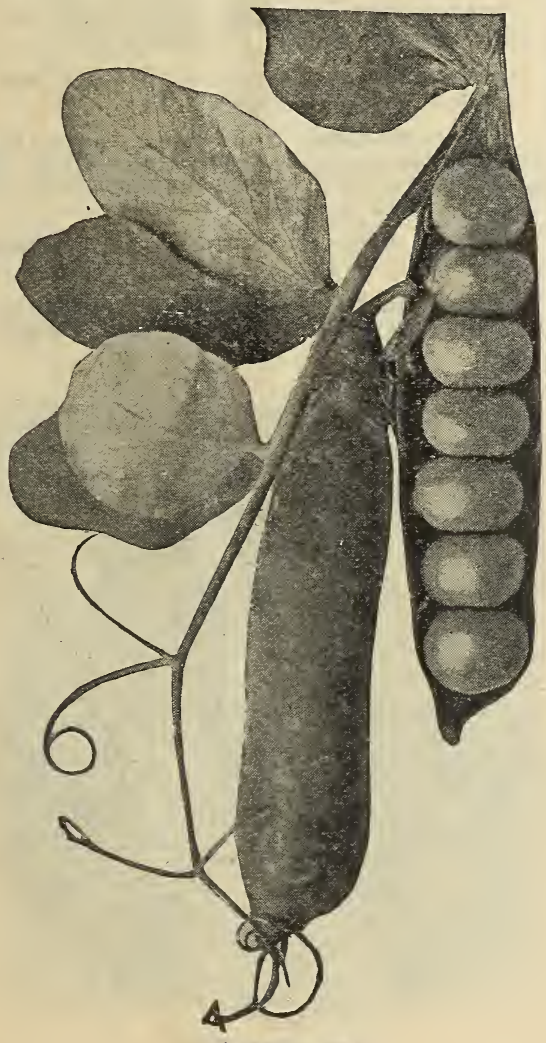

Alaska Peas

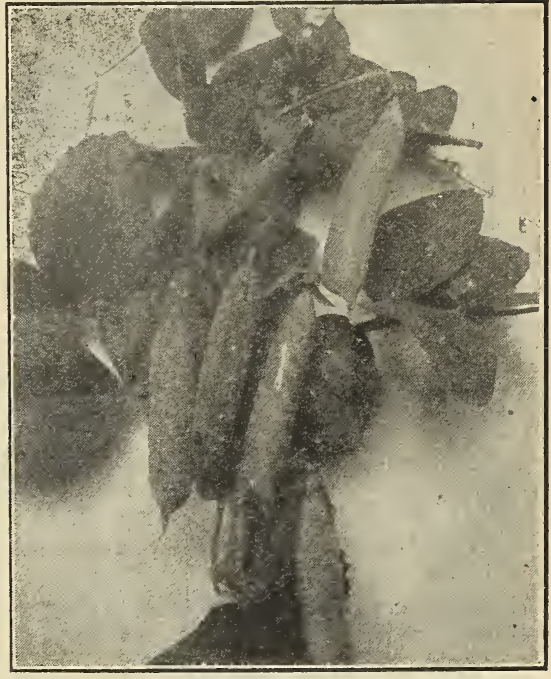

Nott's Excelsior

*NOTT'S EXCELSIOR-the Finest Dwarf Wrinkled Extra Early Variety-It is the best of recent introductions; vines are larger and more vigorous than the American wonder, while the pods are fully one-third larger, containing six to eight fine large peas, packed so closely together in the pods that the peas are always more square than round. The pods are always well filled with peas, which in sweetness and quality have no equal, being superior to any other wrinkled sort.

*THOS. LAXTON-The only rival to the famous Gradus, as a long-podded, extreme early wrinkled pea, and in some respects even better. The growth is identical, but the pods are a deeper, richer green and square at the end. In the judgment of experts, Thos. Laxton is even sweeter and finer in flavor, while as the large peas are of a deeper green they present a more attractive appearance on the table.

*LITTLE MARVEL-Similar to Nott 6 Excelsior; better quality; height, $3 / 6 \mathrm{ft}$ 


\section{PEAS-Continued}

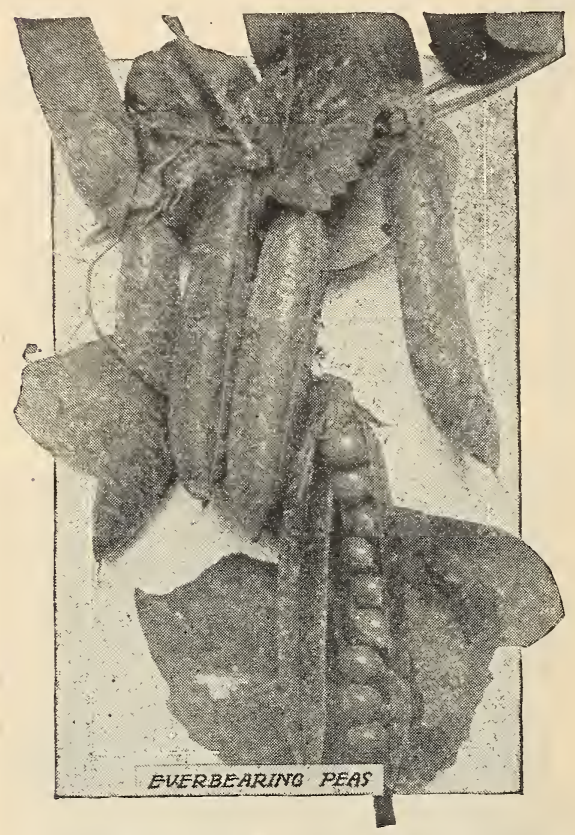

ALASKA-One of the very earliest blue peas; quite productive. Height, $21 / 2$ ft.

-american wonder-N e a r l y as early as Alaska, a good yielder, extra quality. Height, $\$ / 4$ ft.

FIRST AND BEST-Early, resembling Early New Yorker. Helght, $2 \frac{1}{2} \mathrm{ft}$.

EXTRA EARLY TOM THUMB-Wellknown old variety. Height, $\% / 4$ ft.

*LITTLE GEM-McLean's very desirable early pea, great producer, good quality. Helght 1\%4 ft.

* PREMIUM GEM-Earlier than Little Gem, better quality. Height, 1 ft.

RURAL NEW YORKER-Very early; prolific and uniform in ripening. Height, $21 / 2 \mathrm{ft}$.

\section{Early and Medium Peas}

Special Price on Quantity.

*ABUNDANCF BLISS-Medium early; vine fine. Height, $1 \frac{1 / 8}{\mathrm{ft}}$.

DWARF TELEPHONE OR DAISY - A medium late pea that needs no brushing. It is of dwarf, stock habit, healthy, vigorous growth, and productive, bearing large, handsome pods and peas of highest quality.

* everibearing-Long pods a n d large peas; sow thin. Height, $2 \% \mathrm{ft}$.

-HORSEFORD MARKET GARDENOn the atyle of Advancer; very prolific. Helght, $21 \%$ it.
* Melain advancer-A fine standard sort of excellent quality. Height, $21 / 2$ ft.

PRIDE OF THE MA R K T-Pods large. Height, 3 ft.

*TELEPHONE-Very valuable, vigorous grower, pods large, sweet. Height, 4 fit.

\section{Late Peas Special Price on Quantity.}

* CHAMPION OF ENGLAND-A wellknown standard pea; sow thick. Height, $5 \mathrm{ft}$.

*DWARF W R I N KLED SUGARLarge, well-filled pods, very productive. Height, $1 \frac{1 / 2}{2 t}$.

* Heroine-Large, full pods, enormously productive. Height, $2 \frac{1 / 2}{\mathrm{ft}}$.

MARROWFAT, BLACK-EYED-T $\mathrm{h}$ e best Marrowfat. Height, 4 to $5 \mathrm{ft}$.

$M A R R O W$ F A T, WHITE-An old standard sort, quality inferior, great yielder. Height, 4 to $5 \mathrm{ft}$.

MAMMOTH SUGAR-Gray seed, immense edible pods. Height, $5 \mathrm{ft}$.

MELTING SUGAR-One of the best edible pod sorts. Height, $4 \mathrm{ft}$.

*STRATAGEM-The finest s e c o nd early, vigorous and productive; elght to ten large peas in pod, unsurpassed in quality. Height, 2 to 3 ft.

TALL, SUGAR-White seed, edible pod. Height, 5 ft.

- yorikshire Hero-A spreading variety, very productive; sow thin. Height, $2 \frac{1}{2} \mathrm{ft}$.

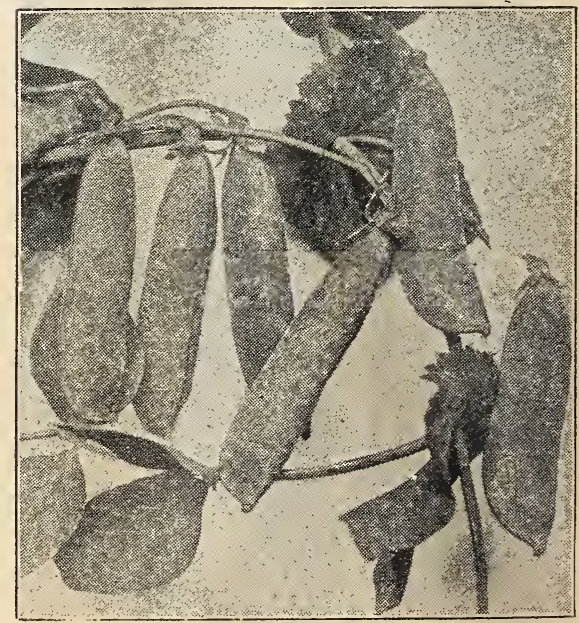

Stratagem Peas 


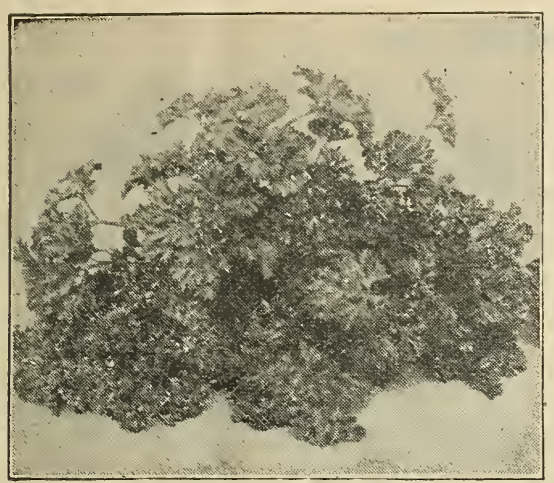

Mosy Curled Parsley

\section{PARSLEY}

CULTURE-Soak the seeds a few hours in luke-warm water, and sow early in the spring until the middle of July, in drills one foot apart. Thin out the plants to four inches. To preserve in winter transplant to a light cellar or cold frame.

DOUBLE CURLED-Superior.

CHAMPION MOSS CURLED-V e $\mathrm{r}$ y pretty and one of the very best.

FERN-LEAVED-Fine curled.

H A M B U R G OR ROOTED-Edible roots, much like parsnfps.

\section{PEPPER}

CULTURE-Sow in hotbeds in $\mathrm{March}$, and when the soll has become warm, set in rows two feet apart and eighteen inches in the rows, hoe frequently and keep down all weeds. The plants may also be forwarded in pots.

CELESTIAL-A Chinese Pepper; at first fruit is yellow, and when fully matured becomes a deep scarlet.

CHINESE GIANT (see cut)-A very large, fine, mild red pepper. Not only is it immensely productive for so large a pepper, but its enormous size and magnificent appearance make it sell most readily. The plants are vigorous in

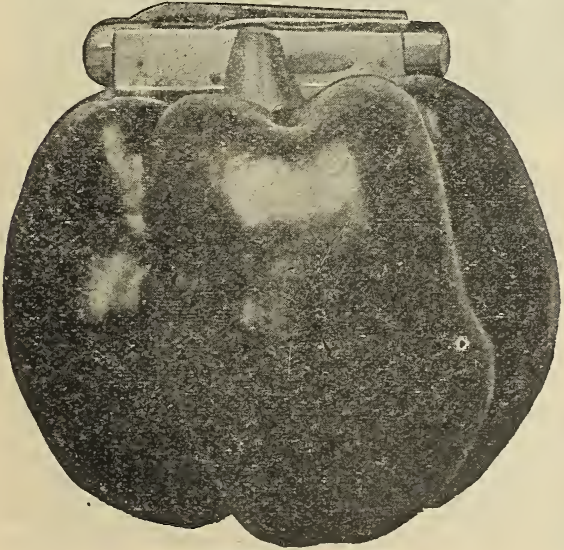

Bull Nose growth, well branched and thickly set with enormous fruits. Fruits blocky, 4 to 5 inches broad, color brilliant scarlet.

LARGE BELL OR BULL NOSELarge and mild, excellent for pickling.

LONG RED CAYENNE-Bright red, very productive.

RED CHERRY-Cherry shaped; for pickles, for which they are largely used.

RED CLUSTER-A new type of Chili, with upright bright red fruits.

RUBY KING-Beautiful bright red, large fruit, mild, one of the best; fine for pickles.

SWEET G O L D E N QUEEN-Very handsoms and distinct, and of mild flavor.

SWEET MOUNTAIN-Large, regular and of mild flavor; one of the best for pickling.

\section{PARSNIP}

HOLLOW CROWN-A market gardener's strain.

LONG SMOOTH WHITE-Long, white, smooth, no side roots; tender and excellently flavored.

STUDENT-A half-long variety of delicious flavor.

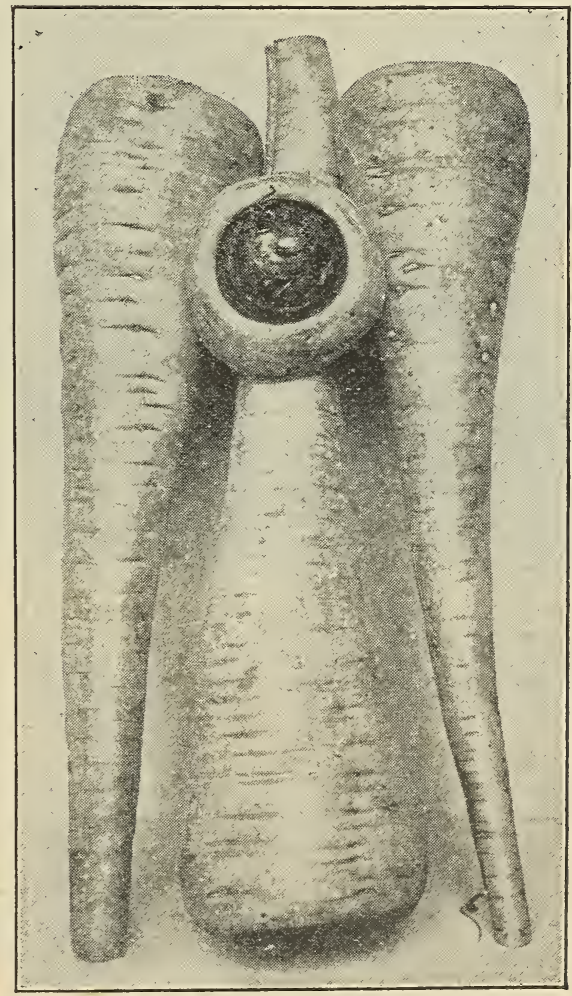

Hollow Orown 


\section{Seed Potatoes}

It is not advisable to plant potatoes from crops that did not yield well, or contained a large percentage of small or irregular tubers.

By using potatoes from hills with weak vines and poor, small potatoes, the number of poor hills is largely increased each season until the yield is greatly reduced.

By selecting seed from the best hills and using them for seed a strain of potatoes that will yield twice as much as common seed can easily be produced.

We can furnish seed grown from seed selected from the best hills only which will be found far superior to ordinary potatoes for planting.

We notice when using this selected seed that the vines are stronger and more vigorous than usual, and there are no poor, weak hills. Every hill seems to be jus: like another and all produce a good lot of even size potatoes.

CULTURE. Any good soil will produce Potatoes, but quality is much improved when produced on good sandy loam. Make furrows of good depth, three feet apart, scatter a liberal dressing of fertilizer in the drill. Cover slightly with earth and upon this set the seed Potatoes in hills one and one-half feet apart. If a very early crop is desired, it will be necessary to sprout the Potatoes before planting. Cut the Potatoes in pieces of the size desired and place in a warm light room for four days before required for planting in the open ground.

Use Bordeaux mixture for blight and arsenate of lead for the Colorado beetle, or if, as is often the case, both these conditions prevail, use the two in combination. We recommend Pyrox (Bowker's) for this purpose knowing it to be effective, and we believe it will also increase the crop and improve the quality.

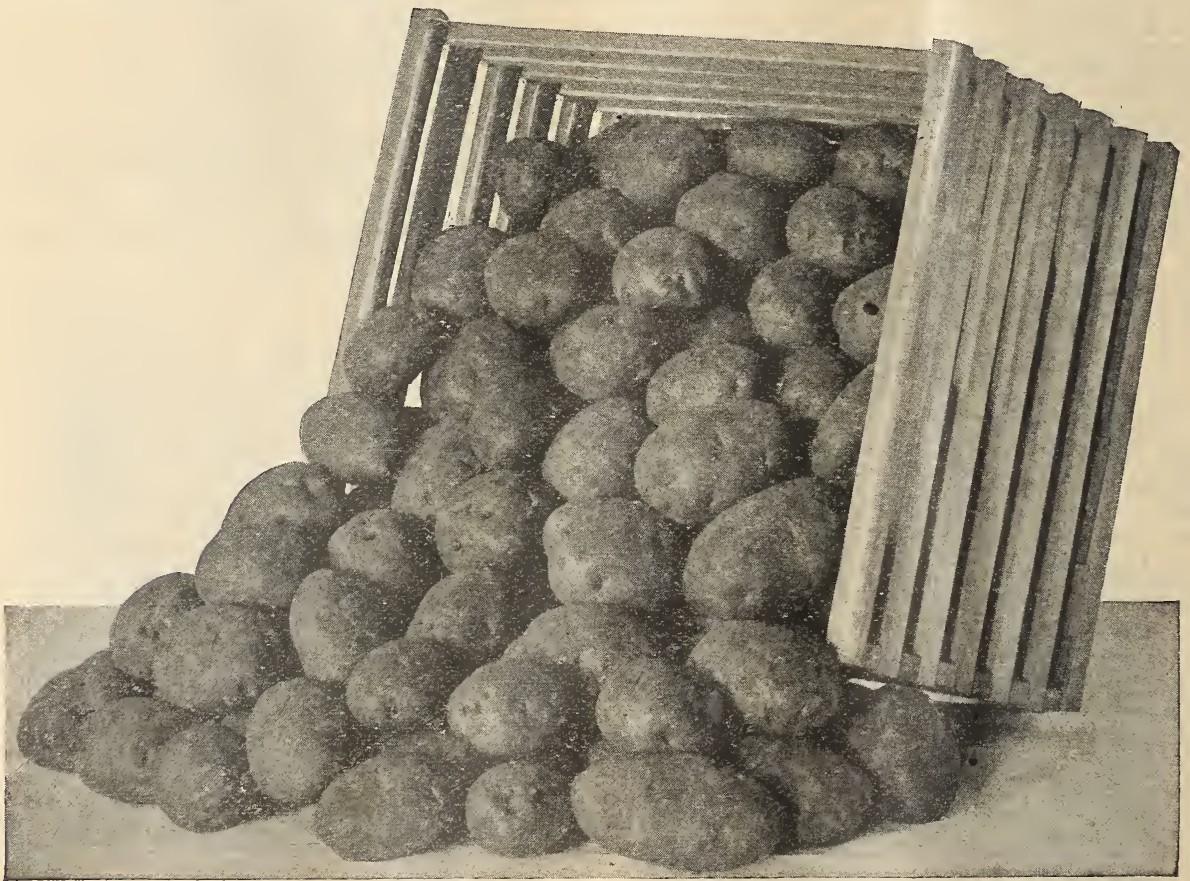

EARLY OHIO. The standard early potatoes; medium long with square ends; color, light red, deeper around the eyes. Vines small and die down very early. Often yields very large crops under high culture.

EARLY ROSE. Probably the most popular early potato ever raised in this country. It has been the standard for yield and quality for thirty years. There is very little true Early Rose seed to be had, but we are glad to be able to offer some genuine stock grown under the "hill-unit" system and possessing the old-time vigor and quality. The potatoes are oblong and light red with shallow eyes. They yield well for an early kind and the quality is of the best.
EARLY SURPIRISE. We are very much impressed with the value of this new potato. While not a strictly early variety it grows rapidly and if planted early will produce big, smooth, white potatoes only two or three weeks later than the extra early kinds that do not yield over half as much. This will prove a profitable variety to market between the early and the late crop. It will yield as much as almost any late kind, and the potatoes are pure white, round, smooth and attractive in appearance and of fine quallty. The vines are vigorous and healthy and usually produce 6 to 8 good, large potatoes per hill. It is not difficult to get 200 bushels per acre and the potatoes are so smooth and handsome that they bring the highest prices. 


\section{Irish Cobblers.}

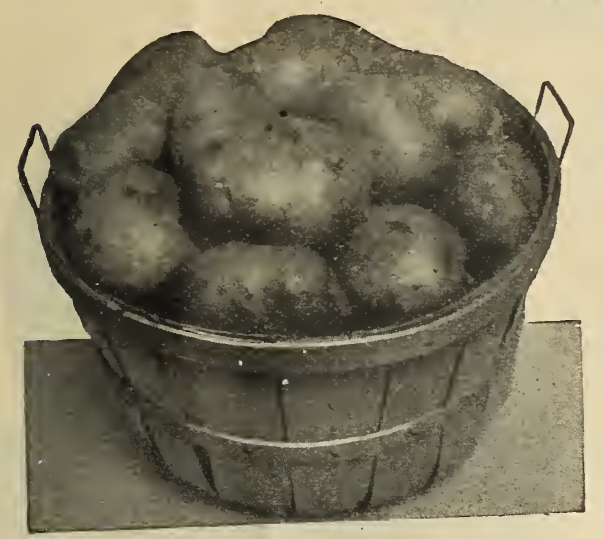

Next to Early ohio Irish Cobbler In the Most Popular Farly Potato.

Irish Cobbler has been for some years the most famous early potato in the east. It is raised extensively by the truckers there to supply the eastern market and from there its popularity has spread throughout the whole United States.

It is a most excellent early variety, maturing good sized tubers seven weeks from time of planting. It has the remarkable characteristic of producing very few, if any, small tubers, all the tubers being of marketable size. The vines make short, upright growth so that the hills may be only a short distance apart. The flesh is pure white with a clean, smooth white skin and in quality they are excellent, cooking very dry and mealy. They are splendid peelers and a first class sort worth the attention of all the potato growers.

\section{Sir Walter Raleigh.}

\section{Brings the Highest Main Crop Price. Finer Grained and Whiter Flesh Than \\ other Variety.}

Sir Walter Raleigh is a perfect main crop potato and peedling of Rural New Yorker. Good size, hardly Porker. any small ones, nearly ever skin pure white, eyes few and very shallow. Potatoes never shallow. or pronged and a scablight resister. A sure great blight in yielder where other soils. clay soils and other soils. It can be justly claim is the Sir Walter Raleigh is the whitest fleshed and finest grained poin crop varieties. list of main crop On trial grounds of the Rural New Yorker it proved the best and heaviest cropper of 49 and heaviest is the type of potato bringing the highest price on every market and it yields well.

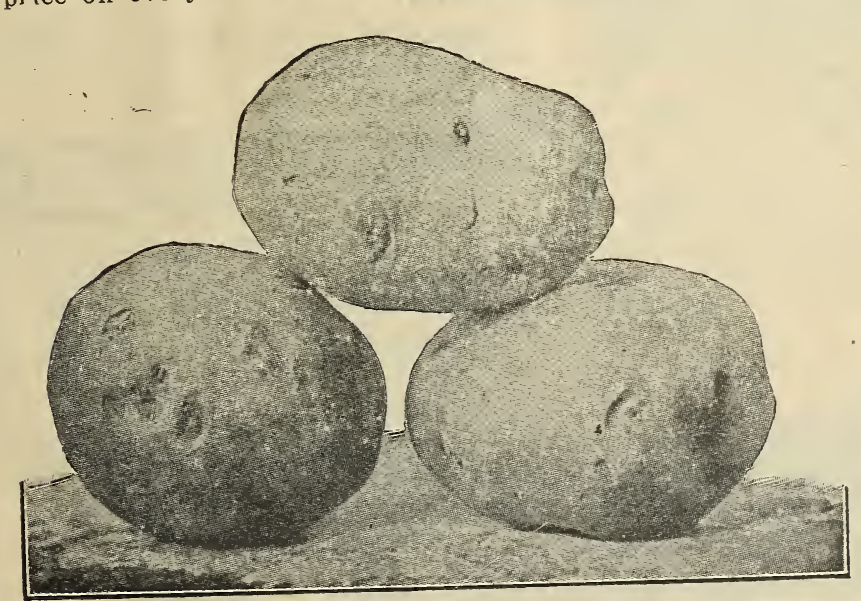

Rural New Yorker

Rural New Yorker Has Been the Standard Late Variety.

The Rural New Yorker is more largely grown in the potato growing states than any other late potato and is the type of potato preferred on the markets. They are large and unusually smooth with a few shallow eyes, skin white as is also the flesh which is of superior quality. They are medium late and the best drouth resister.

This is a potato that should especially recommend itself to those who want the best to be had in a medium late market potato. 


\section{Pumpkin}

CONNECTICUT FIELD-Grown for stock; very productive. color.

GOLDEN CUSHAW-Fine golde $\mathrm{n}$

K E N T U C K Y FIELD-Grown for stock; very productive.

LARGE CHEESE-Flat; one of the best varieties for family use; good keeper.

MAMMOTH POTIRON-Grows to an enormous size, 150 to 275 pounds; fine for exhibition.

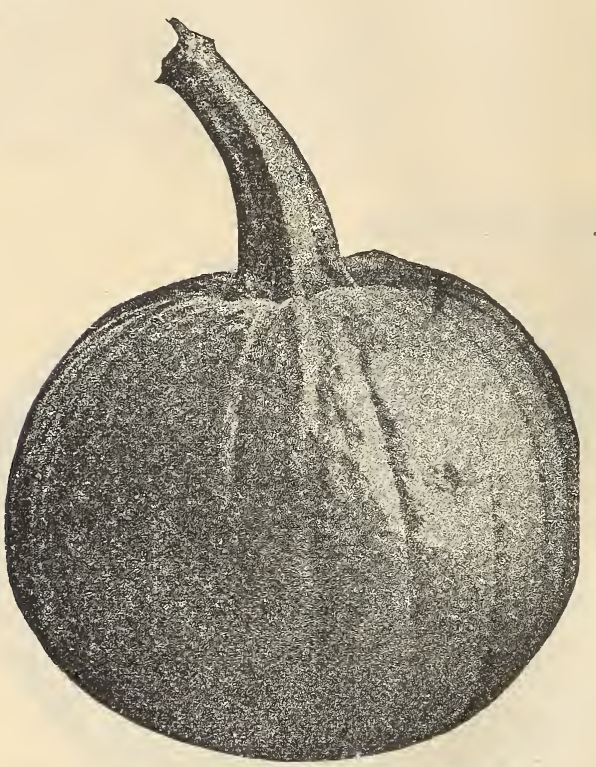

Large Cheese or Kentucky Field

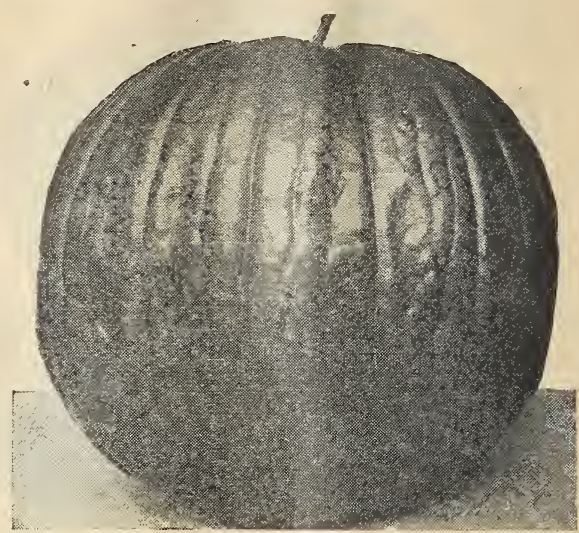

Connecticut Field

MAMMOTH TOURS-A very large French variety.

QUAKER PIE-Fine for pies, very prolific and a good keeper.

RED ETAMPES-Medium size, flat, fine for cooking.

STRIPED CUSHA W-M e $d$ i u $m$ size, crookneck, very productive.

SWEET OR SUGAR-Fine grained, sweet and prolific; small yellow, best for pies.

TENNESSEE SWEET POTATO-Bell shaped; thick, white flesh, fine for pies.

WHITE CUSHAW-Fine white color.

\section{Rhubarb seed.}

CULTURE. Sow the seed in cold frame in the spring and as soon as the plants are large enough to transplant in rows 1 foot apart each way and cultivate. The following spring, plant out in rows 5 feet apart each way and each spring work into the soil a liberal supply of decomposed stable manure. Rhubarb roots are set out and cultivated as the above and this method gives edible rhubarb in a very short time. row.

One ounce of seed will sow 75 feet of

LINNAEUS-The earliest. quality.

MAMMOTH-Very large, but good small.

VICTORIA-Very fine in quality, but

ROOTS

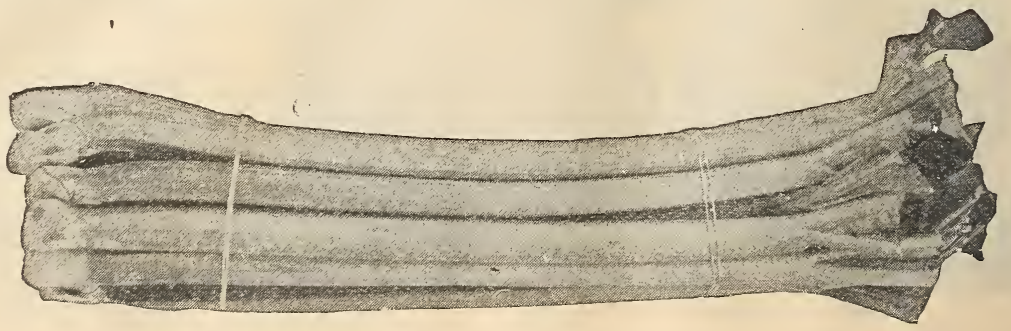




\section{Radishes}

Sow seed $1 / 2$ inch deep in the early spring in rows 1 foot apart and the more fertile the soil the faster they will grow. For a succession, sow every 10 days throughout the season and stir the soil sufficient to keep out weeds.

One ounce of seed required for 100 feet of row; 8 to 10 pounds of seed will plant one acre.

Ready for use from 18 to 25 days.

CRIMSON GIANT-This we consider the greatest new radish in the last ten years. It is of American origin. It is an early radish, looking much like the old Early Scarlet Globe, but more perfect in shape and color. It comes as early as any radish, but the amazing thing about it is that it keeps on growing and remains tender, solid and sweet, till it gets as large as a teacup or larger. Just imagine the nicest Scarlet Globe Radish you ever saw, deep red outside and pure white inside, fine flavor, and as large as a teacup and you will have a good idea of it.

FRENCH ..BREAKFAST-Earliest, most handsome, tender and crisp. Deep, glossy crimson with white tips.

*LONG SCARLET SHORT TOP-Very long and crisp, for frames and open ground.

*LONG BRIGHTEST SCARLET-White tipped, very bright and beautiful.

\section{*LONG SCAR:ET CHARTIER WHITE} TIPPED-Shades from crimson to white: tender.

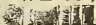

*LONG WOOD EARLY FRAME-Long, red, crisp, and good for forcing.

LONG WHITE VIENNA OR LADY FINGER-Crisp and tender in summer; one of the best.

OLIVE-SHAPED WHITE-Mild and fine for summer.

*OLIVE - SHAPED FRENCH BREAKFAST-Pink and white, early; standard sort.

*ROSY GEM-One of the very best for market gardeners; very early, tender, beautiful scarlet, shading off into a white tip.

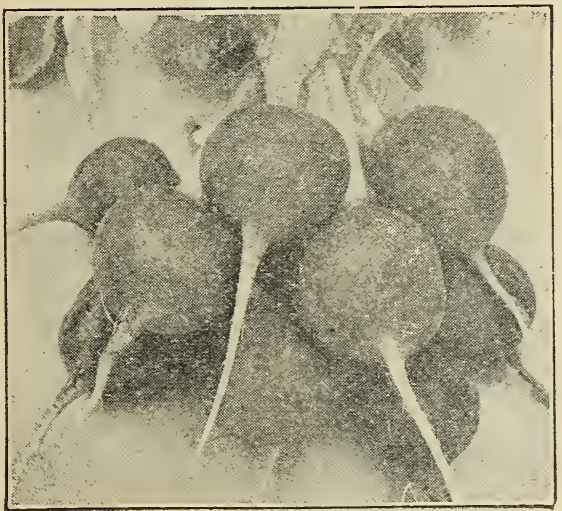

Crimson Giant
*THE ICICLE-A new introduction of the Long White; beautiful ivory white color : fine slender form, quality excellent; very early; fine for market.

TURNIP EARLY SCARLET-Very early, crisp; good forcing.

TURNIP EARLY DEEP SCARLET-VEY early; used for forcing.

TURNIP EARLY SCARLET WHITE TIPPED-Very early for frames or outdoors. This is one of the best for market gardeners.

*TURNIP EARLY NE PLUS ULTRAExtra early scarlet forcing, short leaved.

*TURNIP EARLY DEEP BLOOD REDExtra early forcing sort.

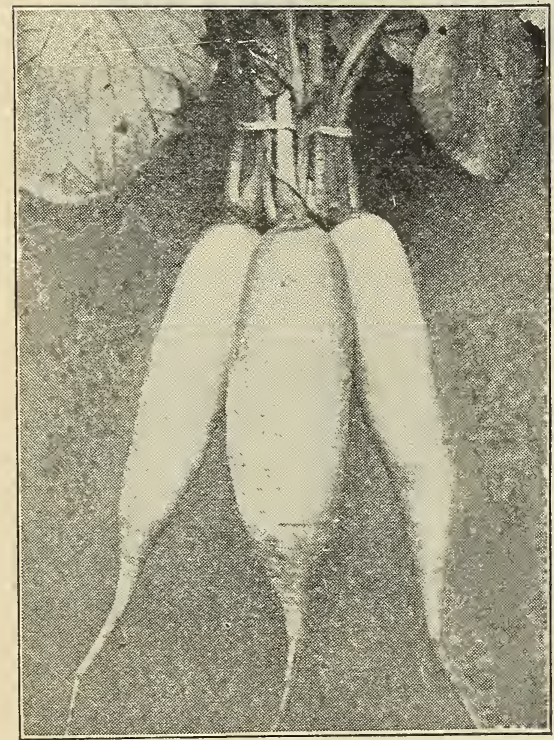

White Icicle

*TURNIP EARLY WHITE OR BOXSuitable for forcing, fresh, pure white and sweet.

TURNIP ..GOLDEN ..SUMMER-Smooth and bright skin.

TURNIP GRAY SUMMER-Good solid summer sort.

TURNIP YELLOW SUMMER-Dull yellow, fine flesh.

WINTER CALIFORNIA WHITE MAMMOTH-A very large white winter variety.

WINTER LONG BLACK SPANISHThe popular winter sort.

*WINTER ROSE CHINA-Velry haindsome and distinct, and keeps well.

WINTER ROUND BLACK SPANISHFine for winter.

*WHITE STARSBURG SUMMER-Very large; the German's favorite; quality fine.

WHITE STUTTGART SUMMER-Very early and very large. 


\section{Squash}

BAY STATE-With hard, blue shell; for fall and winter.

BOSTON MARROW-Oval, bright orange, flesh yellow and fine.

CANADA CROOKNECK-Small, wellknown winter sort, green skin.

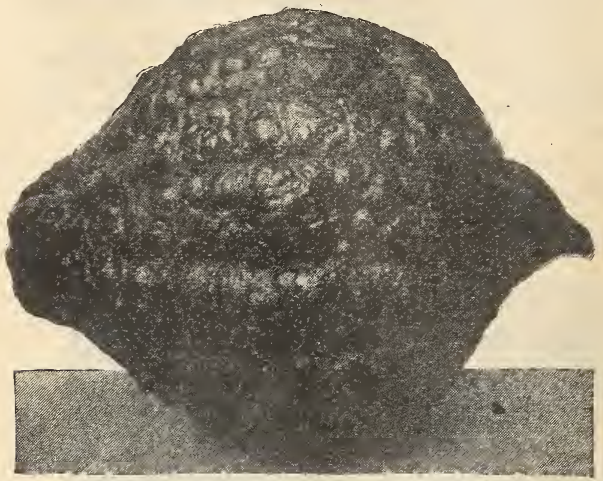

Hubbard

EARLY GOLDEN BUSH SCALLOPFine for summer use, not as early as the White.

EARLY WHITE SCALLOP BUSH-A good early shipping variety, best scallop.

EARLY ORANGE MARROW-An improved Boston Marrow; quite distinct, very early and of most delicious flavor; suitable for fall or winter.

EGG PLANT BUSH SQUASH-A white fleshed bush variety, oval in shape; suitable for frying like Egg Plant.

ESSEX HYBRID-A good fall and winter sort.

FORDHOOK-One of the best winter squashes; fine quality, bright yellow.

GOLDEN SUMMER CROOKNECKOne of the very best summer squashes.
HUBBARD-Well known and liked for late use; of superior quality

M A R B L E H A D-Resembling the Hubbard, but has gray skin

MAMMOTH CHILI-Grows to an enormous size; rich, orange yellow.

PERFECT GEM-Round, white, fine quality, productive, good for fall or winter.

PIKE'S PEAK OR SIBLEY-Thick, bright orange flesh, fine winter sort.

PINE APPLE-Peculiar shape, white skin and flesh; fine late sort.

RED OR GOLDEN HUBBARD-Fine reddish or golden color, large size, fine quality.

THE FAXTON-Medium size, very early, productive; orange flesh of fine quality.

TURBAN-Orange yellow flesh of good flavor.

WARTY H U B B A R D-More warty, harder shell, better keeper, true stock.

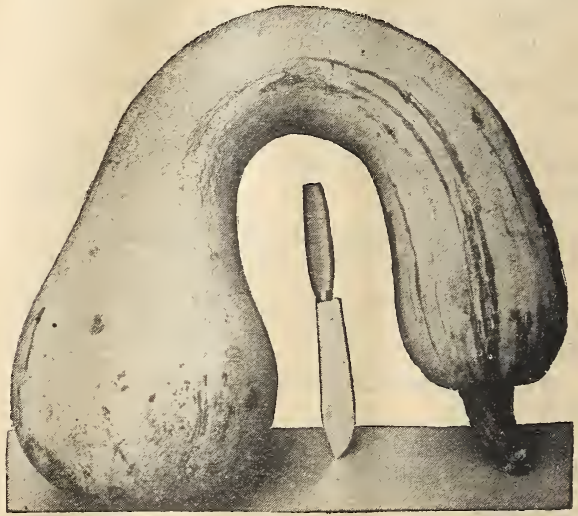

Crookneck

\section{SPINACH}

CULTURE. For early spring use, sow seed in August in very fertile soil rich in humus. Upon approach of cold weather, cover the plants with 3 inches of straw. In the spring, when dry, remove the litter and the plants will be ready for use in a short time. Sow the seed 1 inch deep in rows a foot apart. For a succession, sow again early in the spring and every two weeks thereafter. Keep surface soil cultivated lightly.

One ounce will sow 100 feet of row; 10 to 12 pounds seed required for an acre.

VIROFLAY THICK L E A V ED-Has very large and thick leaves.
C U R L E D - L E A V D SAVOY OR BLOOMSDALE-Large, tender leaves, fine. LONG-STANDING ROUND THICK LEAVED-Dark green, very long standing before running to seed.

PRICKLY - Vigorous and hardy.

NEW ZEALAND-Entirely different from the tree Spinach in type and in that it thrives during hot weather and in any soil, rich or poor. The tender shoots are of good quality and may be cut throughout the summer. Plant three or four seeds in hills two feet apart each way. This Spinach can be used in August or September or up till frost. By using only the leaves it will sprout out again.

\section{SALSIFY, or Vegetable Oyster}




\section{Tomatoes}

CHALI'S EARLY JEWELL-An extremely early variety of brightest scarlet color, deep fruited and solid. Very few seeds and of excellent flavor.

EARLIANA-It is a full week ahead of all others. Plants of strong growth and very productive. Fruits large, deep red, and of superior quality. Smooth and free from cracks.

MATCHLESS-Extra large, smooth and handsome; bright red, very solid.

PONDEROSA-The largest variety in cultivation.

\section{ATLANTIC PRIZE-T h e} earliest of all; smooth, bright red and solid.

DWARF CHAMPION-Quite distinct in foliage and habit of growth, being compact and upright; fruits early and resembles Acme in appearance.

IGNOTUM-Very prolific, earliest of the large, deep red, smooth variety.

PERFECTION (Livingston)-E a r 1 y, regular and productive, red, heavy cropper.

F.A VORITE (Livingston)-Large, smooth, productive and good shipper.

B E A U T Y (L i v i n g s t o n)-Large, smooth, pinkish red, thick flesh, regular form.

STONE (Livingston)-Very large, perfectly smooth, fine bright scarlet; best main crop.

ACME-Medium, red, smoot h and good; one of the best earlies.

EARLY ADVANCE-Bright red, medium sized, smooth, solid, very early.

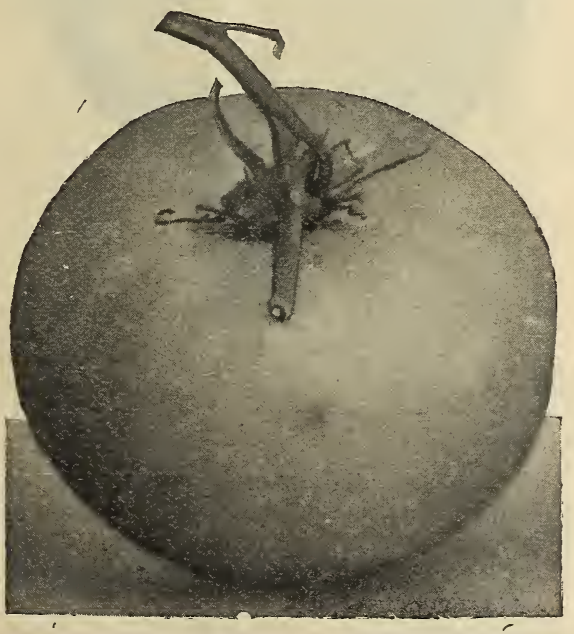

Ponderosa.
ROYAL RED-A first-class main crop variety; skin and flesh intense red.

TROPHY, LARGE-Very solid, standard late sort, grown extensively for canning.

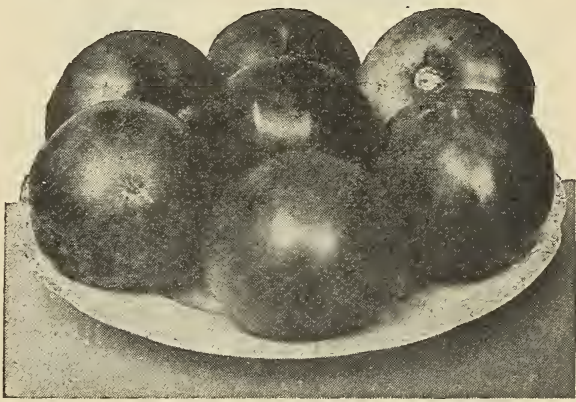

Early Jewel

YELLOW PLUM-Round asid regular, bright yellow; used for pickles

PEACH-Resembles a peach, for preserves, pickles and exhibition; quality excellent.

YELLOW PEACH-Very handsome in form, and of a beautiful clear yellow color; is useful to contrast with other sorts.

RED CHERRY-Fruit about an inch in diameter, in bunches; used for pickles.

YELLOW CHERRY-Similar to preceding, save in color.

RED PEAR-SHAPED-Fruit of peculiar shape, handsome and solid.

GROUND CHERRY (Husk Tomato)Small and ornamental fruit used for preserves.

GOLDEN QUEEN-Large size, handsome, very smooth, good quality.

GOLDEN TROPHY-Similar to the 


\section{Turnips}

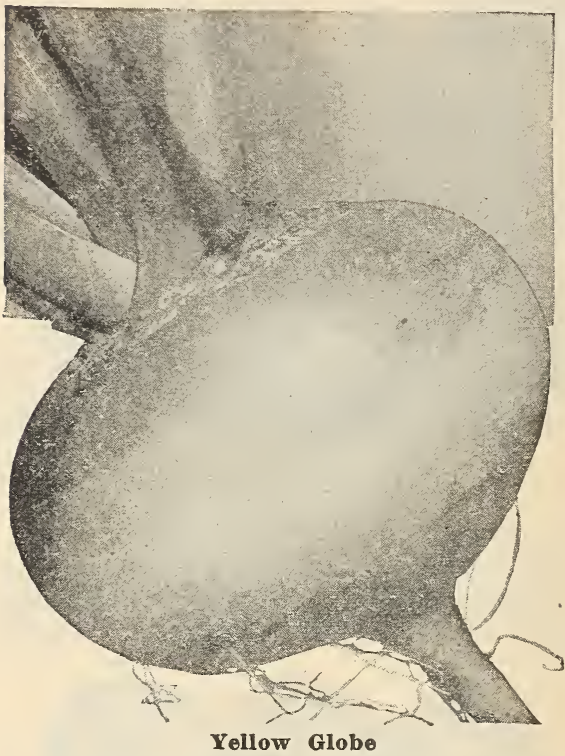

COW HORN-Early and good; shaped like a Nantes carrot.

EARLY MILAN WHITE-Very early, white top.

EARLY MILAN PURPLE-Earliest of all; with purple top.

EARLY DUTCH-Rather flat; good white early sort.

GOLDEN BALL OR ORANGE JELLY -Very handsome; keepsifairly well.

POM E R A I A N WHITE GLOBELarge, good for both table and stock.

PURPLE TOP STRAP LEAF-The popular flat fall sort; sweet, firm and mild.

PURPLE TOP WHITE GLOBE-A standard sort in the New York market; nothing better.

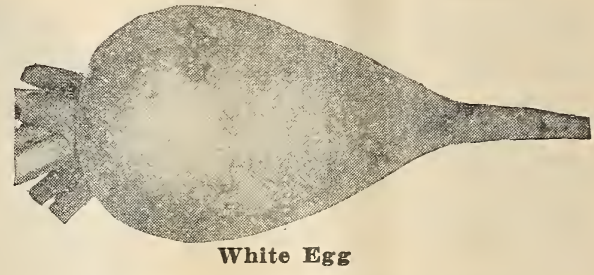
sweet.

WHITE EGG-Oval, handsome and

WHITE GLOBE-Good e ithe $r$ for table or stock; one of the best.

WHITE NORFOLK-Globular, late, solid, very large, fine for stock.

WHITE STRAP LEAF FLAT-A good early white flat sort.

YELLOW GLOBE-Good and sweet; keeps fairly well.

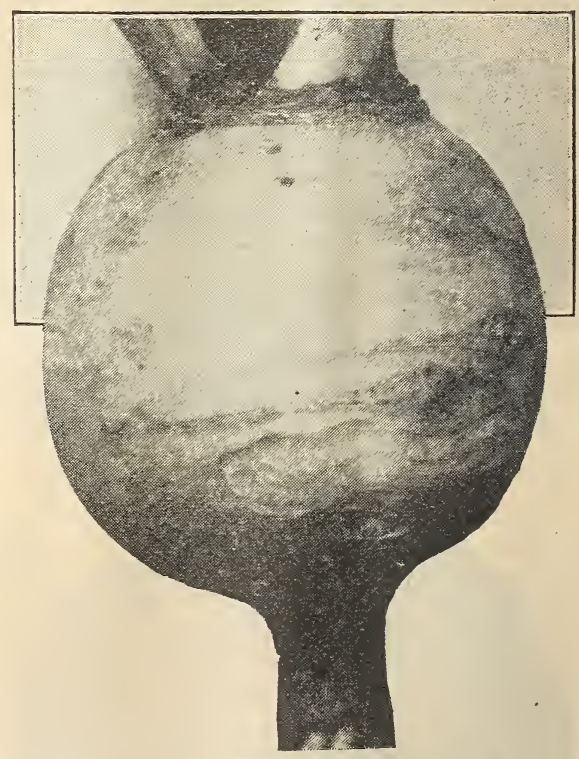

Snowbull

\section{RUTABAGA, or Swedish Turnip}

MONARCH-Distinct in form; a grand, good variety; very large yielder; grown mostly above the ground; flesh rich yellow.

MMPROVED AMERICAN PUR PL E TOP-Very hardy variety; flesh yellow, sweet and well flavored; deep purple; has but little neck.
CARTER'S IMPERIAL HA R D Y A purple topped variety, growing to a large slze, single to root; good flavor.

WHITE SWEED OR RUSSIAN-EXcellent variety for either table or stock; white flesh, flne flavor, good keeper. 


\section{Flowers}

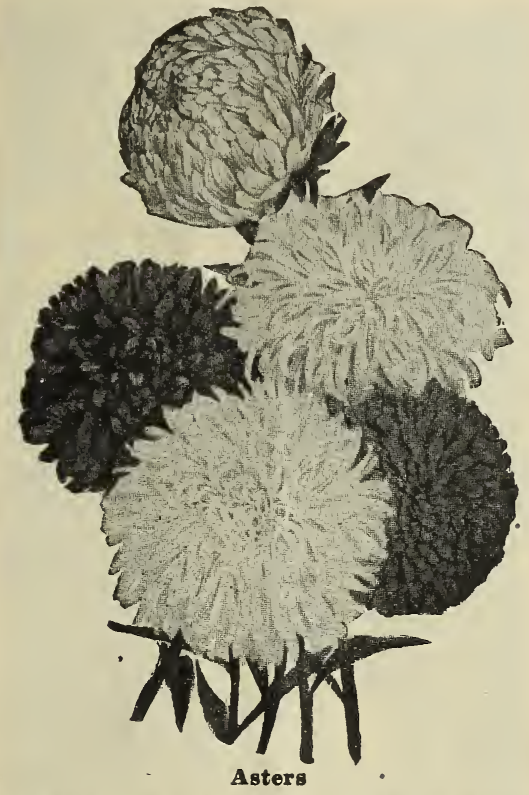

AGERA TCM. A beautiful, hardy annual, covered with bloom all summer.

ALYSSUM. Sweet-scented, hardy annual, blooms early in the spring; a pure wihte flower, and continues to bloom until late a $u$ tumn. Little Gem, annual; Saxtile, yellow perennjal.

AMERICAN ASTER. It is to be had in three colors: pink, white and blue, combining when the cut flowers are bunched together most effectively the American national colors. This Aster of American origin, one of the largest flowering, late branching sorts, vigorous growth and profuse bloomer with whorled centers as the flower unfolds.

GIANT COMET, BRANCHING TYPE. Mixed.

QUEEN OF THE MAREET TYPE. Very early. Mixed.

BACHELOR'S BUTTON. A favorite hardy annual that produces flowers in many colors. The flowers are mostly in the shades of blue and will reseed themselves, coming up each year.

BALsaM. Known as Lady slipper, and Touch-Me-Not. The colors range from white to dark purple. Hardy annual, one to two feet high.

CALLIOPSIS. Showy border plant, flowers bright yellow or rich brown, either selfcolored or with these colors and red contrasted. All sorts mixed.

CANDYTUFT. Showy, branching plants six to twelve inches high; will bloom from July to September, or if planted in the fall, from May to July.

CASTOR BEAN (RICINUS). Tall, majestic plants for lawns, with leaves of green metallic blue; of very quick growth in rich soll.

CANTERBURY BELLS (Campanula). Very fine hardy plants profusely covered with extremely showy bell-shaped flowers, in single, semi-double and double forms in shades of blue, white and rose with some of the blooms 3 inches in length and 5 inches across of beautiful waxy texture.

CELOSIA (PLUMOSIS). Distinct variety of bush form of growth about 2 feet, branch. ing freely and bearing a profusion of beautiful ball-shaped woolly flower heads of intense scarlet. Sometimes called the Wool Flower. Blooms all summer until the frost comes.

CARNATION MARGUERITE. Easily grown from seed f free blooming; flowers bright with clove-like fragrance; some varietles are suited for house plants; others do best in the open ground. Plant in April. Half hardy perennial.

CENTURIA-CYANUS (BACHELOR BUTTONS, CORN FLOWER) in its improved forms is one of the most attractive of garden flowers. One to two feet high. Double Mixed.

COLEUS or Foltage PLANT. Our seed mixture is saved from plants showing the choicest colors and best shaped leaves. They may be taken up in the fall and potted for house culture or the seed can be sown at any time for house blooming plants. They like good soil and plenty of water and there is nothing better for a border plant or for making solid flower beds.

COREOPSIS. Very showy, free flowering plants, native of this country, fine for borders and beds. Yellow Flowering.

COLUMBINE. One of the best of the hardy plants, bearing flowers of exquisite clear blue, white, rose, yellow, purple and striped colors. A fine plant for the shrubbery border or grown as single specimens.

cosmos. A very effective autumn flower, bush-like plants 3 to 5 feet high, and covered with large single dahlia-like flowers. Mixed.

CYPRESS VINE. A most beautiful climber with delicate, dark green, feathery foliage, scarlet blossoms. Tender, annual.

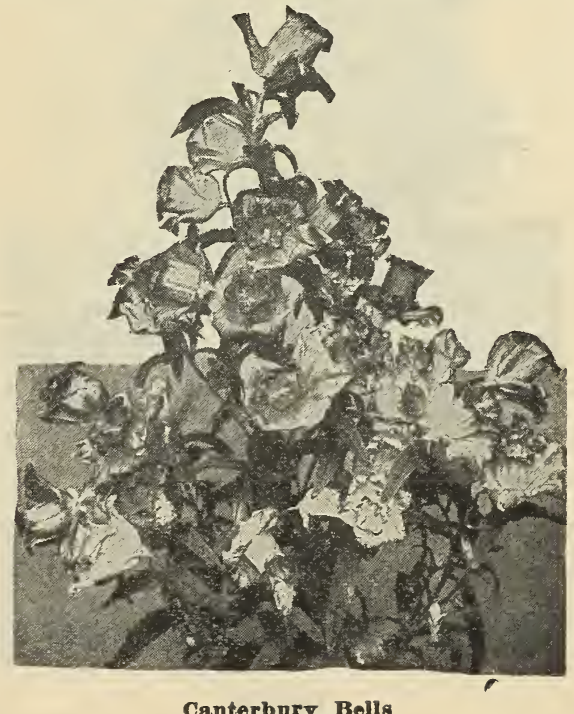

Canterbury Bells 


\section{FLOWERS-Continued}

DAHLIA : Double Large Flowering. Dahlias can be grown the first season from seed. You will get many fine varieties in this way. Our seed is saved from all of the very best of the double flowering and is especially choice. Single Mixed Varieties. There are many very beautiful single flowering dahlias, some of them making a greater display than the double kinds.

EVERLASTING (Helichrysum.) These old-fashioned flowers are still considered very useful. Many of them have fine colors and are very odd shapes and they are well worth growing. If cut when they come into bloom and hung with heads down and allowed to dry gradually in a shaded place they will be straight and perfect in shape and last forever. Our mixture of seed comprises all the best there is in these wonderful flowers.

FEVERFEW. These are fine plants for bedding, growing about 3 feet high, with large double flowers pure white in color. They are well adapted for bedding or as house plants.

FORGET-ME-NOT (MYOSOTIS). A Iavorite old-fashioned flower, bearing in profusion clusters of blue blossoms. It thrives well in the shade or open border. Hardy perennial.

FOUR O'CLOCK (MARVEL OF PERU). The flowers are funnel-shaped and open about four o'clock in the afternoon and remain open all night and generally perish before noon next day; will grow in any soil. Hardy annual, 2 feet high.

FOXGLOVE OP DIGITALIS. Produces long spikes of richly colored flowers that are excellent for cutting. They grow from 3 to 5 feet and are in many colors in white, pink, purple, yellow and many various shades. Excellent for borders.

GAILLARDIA. Single and double mixed. 'There is nothing more admired for their rich

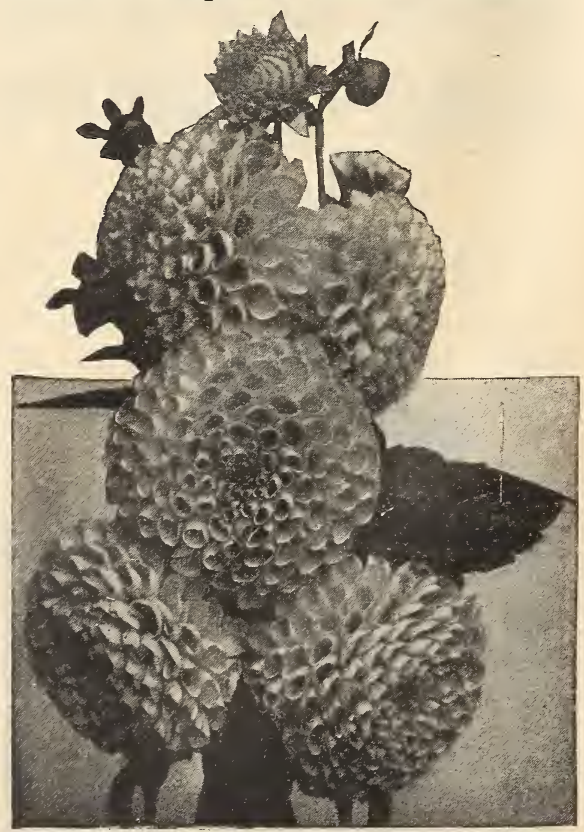

Dahlias

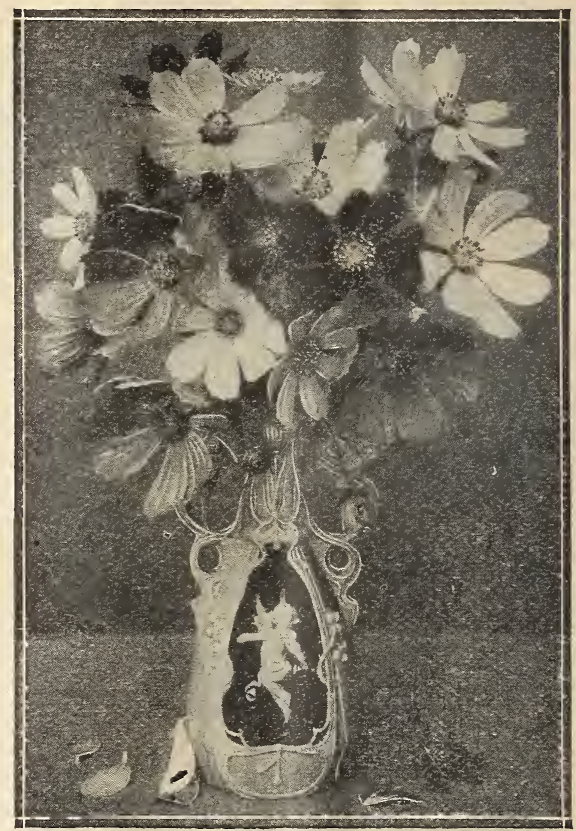

\section{Cosmos}

blending of colors than the gaillardia. They thrive everywhere and their colors are very gorgeous. The plants grow from 1 to 2 feet high and the double daisy-like flowers are very fine for cutting.

GODETIA. Quick growing and profuse flowering hardy annual of showy colors. Easily grown by anyone. Sow seed early in open ground. The equal of an Azalia.

GYPSOPHILA. (Baby's Breath.) Pretty free flowering, elegant plants, succeeding in any garden soil. Their misty white panicles of bloom are largely used for mixing with other cut flowers.

HELIOTROPE. Highly valued for the fragrance of their flowers and duration of bloom.

HOLLYHOCK. Everblooming annual. The annual kind bloom the first year from seed. Sown in May they will flower in August, but if started inside and set out early they will bloom in July. They are free bloomers and continually in bloom throughout the season.

JOB'S TEARS. An ornamental grass known botanically as Coix Lachryma. Grows 2 to 3 feet high, with broad corn-like leaves.

KOCHIA OR SUMMER CYPRESS. (Kochia Tricophylia.) A highly ornamental annual, having a cypress-like appearance. Its bright autumn coloring has given it two other names: "Mexican Fire Plant" and "Burning Bush."

MARIGOLD. Old-fashioned flower blooming in profusion; usually 2 feet high; blooms till frost comes.

MIGNONETTE. A well-known hardy annual, producing exceedingly fragrant flowers. Seed sown in autumn will bloom early in the spring; thrives best in cool temperature; 1 foot high. 


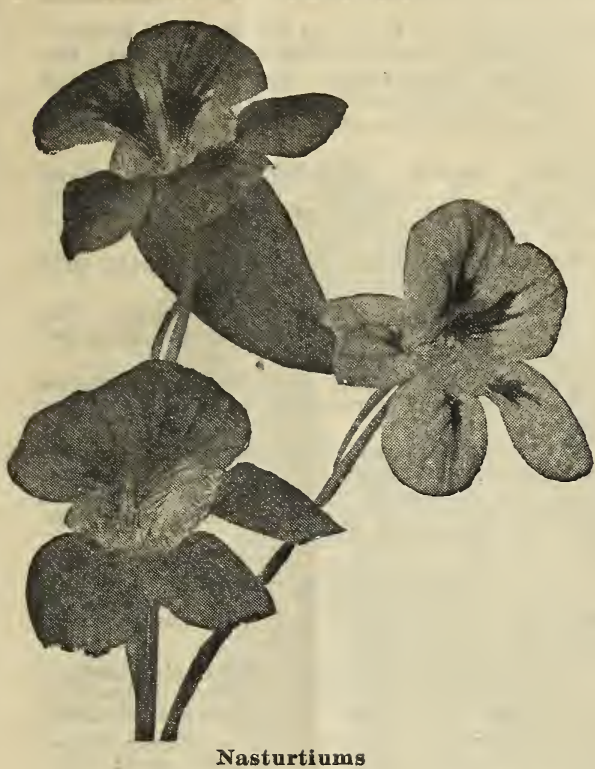

MORNING GLORY. Handsome, showy climber, suitable for covering windows, trellis, old stumps, etc., if support be given the vines. Hardy annual; 10 feet high.

NASTURTIUMS. Giant Climbing. The best of the climbers, as the leaves are the most attractive and the flowers are held out from the foliage better. The foliage is very dark green and the flowers of a great variety of colors measure as much as $31 / 2$ inches across. Dwarf or Tom Thumb nasturtiums are fine for bedding and have large flowers of every known color with a goodly mixing of the darker shades. It is well to plant the mixed, tall and short growing for bedding, as the tall growing hold up the mass of foliage and they make a better effect than as if the dwarf kinds only were planted.

PANSIES. Pansies are now produced in almost infinite variety of form, color and markings. Choice mixed, all colors.

PHLOX. Mixed will produce all the shades in red, crimson, rose, violet and purples and the best in the striped kinds. There is nothing better than the annual phlox for bedding, as its bright colors cannot be excelled. It is one of the easiest of the annuals to raise and gives a wonderful range of colors.

PINKS. For beautiful and lasting cut flowers, ease of culture and freedom of bloom, the hardy garden pinks have no superior among annuals.

POPPIES. No other flower produces a more brilliant display of colors during the blooming period. New Shirley. Oriental Poppy. Eschscholtzia (California Poppy).

PORTUlaca OR ROSE Moss. There are few flowers in cultivation that make such a dazzling display of color in the bright sunshine as a bed of Portulacas. The flowers close in shadow, but are open in sunshlae.

PETUNIA. For freedom of bloom, variety of color and effectiveness these have no equals. A little care bestowed upon them,
Petunias will produce their handsome, sweetscented flowers in delicate and gorgeous colors throughout the whole summer.

SALVIA. The most brilliant colored flowers and extremely useful for bedding. Blooms are of fiery red crimson color, continuing to flower for a long time. Tender perennials: blooms until frost; height 2 to 3 feet. See page 19 for plants.

SALPIGLOSSIS. Very showy bedding or border plants, with richly-colored, funnelshaped flowers, which are purple, scarlet, crimson, yellow, buff, blue and almost black; height, 1 foot. Fine Mixed Sorts.

SMILAX. A climbing plant that holds beauty in its rich dark green shiny foliage. When grown in hanging baskets it droops in a graceful manner that makes it a favorite for that use.

SNAPDRAGON (Antirrhinum.) These tall growing plants have spikes of flowers of very gorgeous colorings, growing to a height of about 2 feet, fine for flower beds or borders, and can be cut back in September and potted for winter flowering. All the best colored kinds are produced from our selection of seed.

STOCKS. The Ten Weeks stocks produces produces immense spikes of perfectly double flowers, measuring from 2 to $2 \frac{1}{2}$ inches in diameter in colors of white, rose, blue, lilac brown and yellow. They are very fragrant and fine to grow for cut flowers. Our assort. ment of seed includes the best colored and double kinds.

SUNFLOWER. The Double Dwarf or Globes of Gold is very double and round in form. They make a stately growth and remain in bloom for a long period. As a background for the garden they are very useful.

SWVEET WILLIAMS. Fine for beds and borders. The seed can be planted in the spring in the open ground and will blossom in the fall. Hardy perennial; $11 / 2$ feet high.

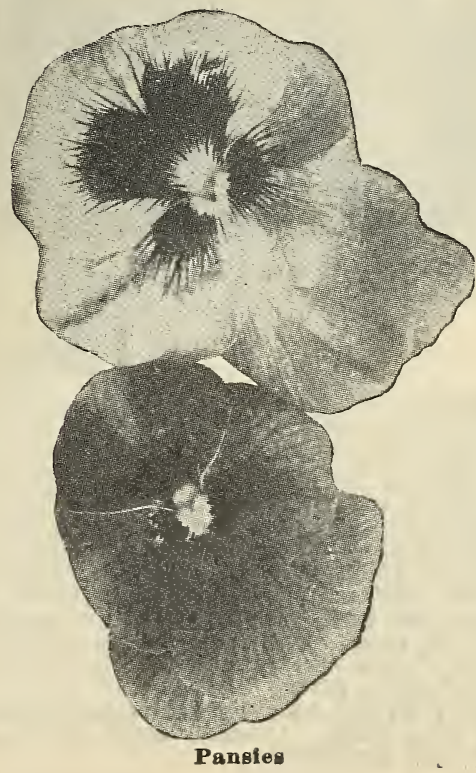




\section{SIVEET PEAS}

Sweet Peas are among the most beautiful of all our hardy annuals. Select a sunny, open place several feet from any building and as far as possible from large trees. Sow as early in the spring as possible. Plant in rows and have the rows trenched for plant. ing 4 to 6 inches deep. In dry weather water freely and keep the flowers picked closely. If allowed to go to seed the plants will stop blooming.

THE SPENCER TYPES are exceptionally large size, with long stems, the wings waved or frilled and the effect remarkably graceful and attractive. We offer what we consider to be the best varieties.

APPLE BLOSSOM SPENCER. (Rose Spencer.) Standard with primrose wings. Very large; true Spencer form.

PINK SPENCER. Some of the flowers

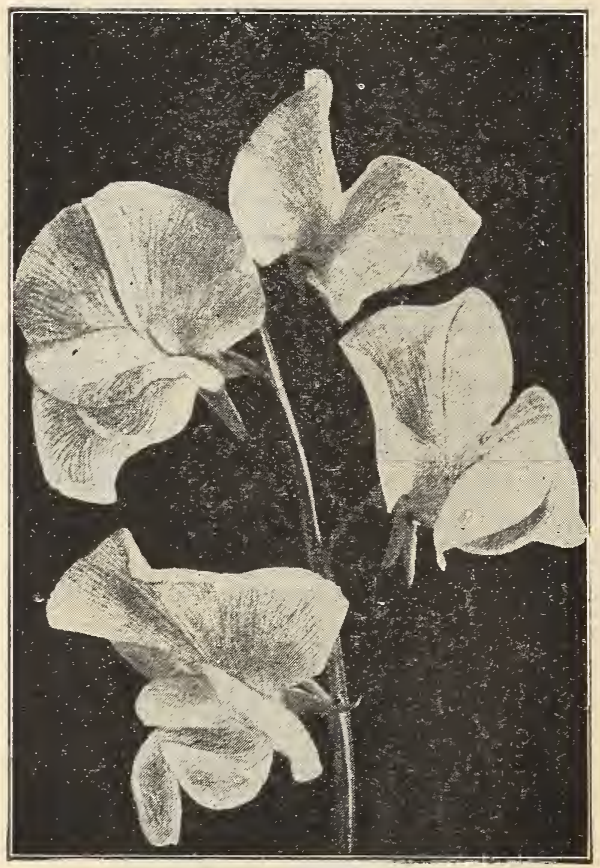

Sweet Peas show striping. It is one of the most attractive varieties ever introduced. Price: plt., 10e.

WHITE SPENCER. Standard and wings of pure white, beautifully waved and lited. An especially attractive variety of very large size.

MRS. HUGH DICKSON (Salmon Pink Spencer). A light on cream background, strong growers; throws four flowers to a stem.

HERCULES (Rose Spencer). A pale rosy pink of giant size.

KING EDWARD VII (Red Spencer). The best pure red Spencer; very large, with especially immense wings.

OTHELLO (Maroon Spencer). Of immense size, with large drooping wings; rich maroon.

SPENCER MIXED. All the Spencer varieties included in making up this magnificent mixture. A splendid range of colors is thus assured in remarkably large size and wonderfully attractive form.

\section{GRANDIFLORA TYPE}

LAVENDER SWEET PEA (Countess of Radnor). Self-colored in a very distinct and beautiful shade of lavender.

WHITE SWEET PEA (Emily Henderson). A well-fornied, clear white flower of medium size. An early, free and persistent bloomer.

MIXED -SWEET PEAS (Grandiflora Type) (Michael's Mixture). All colors, good mix. ture. Contains over twenty varieties.

VERBENA. Sown in May, they will bloom in August, but if started in the house in pots in winter, they will be in bloom sooner. Seeds should be soaked in lukewarm water before planting, and care should be taken that the soil be very rich. Half hardy per. ennial trailer; 6 to 10 inches high.

WALLFLO WER. Dwarf Double Branching Mixed. Wallflowers should be better known, as their adaptability for pot culture and out-of-door bedding and the pecullar sweet fragrance of the flowers makes them a great favorite with all that grow them. The oriental colorings of the flowers in their rich reds and yellows is very effective.

CHINESE WOOL FLOWER. This is the finest type of Celosia there is and has made a great sensation wherever grown. They are easily grown and have a plume-like head of dazzling colors in various shades of dark red and purplish-red. Are very valuable for dec. orative purposes and keep a long time when cut and placed in water.

ZINNIA. Few flowers are more easlly grown or bloom more abundantly throughout the season. Sow the seed early and trans. plant to $11 / 2$ feet apart in good rich soll. Mixed Double, all colors.

\section{Lawn Grass}

In order to secure a close velvety turf, you must use the best grade of grasses. For a carpet-like lawn a mixture of grasses will be necessary; some that will be the brightest, freshest, greenest in the spring, others in the summer, still others in the autumn.

Our lawn mixtures are made up of grasses peculiarly adapted to lawns and door yards, including our cholce Blue Grass and the best known of the creeping or sod-forming sorts. True Sweet Vernal and a very little White Clover enter into all our Lawn Mixtures. One pound of these mixtures will sow about 600 sq. feet of new seeding.

LAWN GRASS MIXTURE.-For quickly producing a permanent, thick and velvety sward of grass, this brand of Lawn Grass cannot be excelled. It is the best mixture of grasses we sell for lawn making, and will give satisfaction wherever sown.

MIXTURE FOR SHADED SPOTS.-Usually it is quite difficult to obtain a satisfactory growth of grass under trees and in shady places; for sowing in such places we recommend the use of this special mixture. It will quickly produce an abundant and even growth of beautiful green grass.

FANCY KENTUCKY BLUE GRASS.-There is absolutely no grass better for a lawn than Fancy Blue Grass. It comes early and stays green until late in the fall. Our seed is pure and of high germination. 


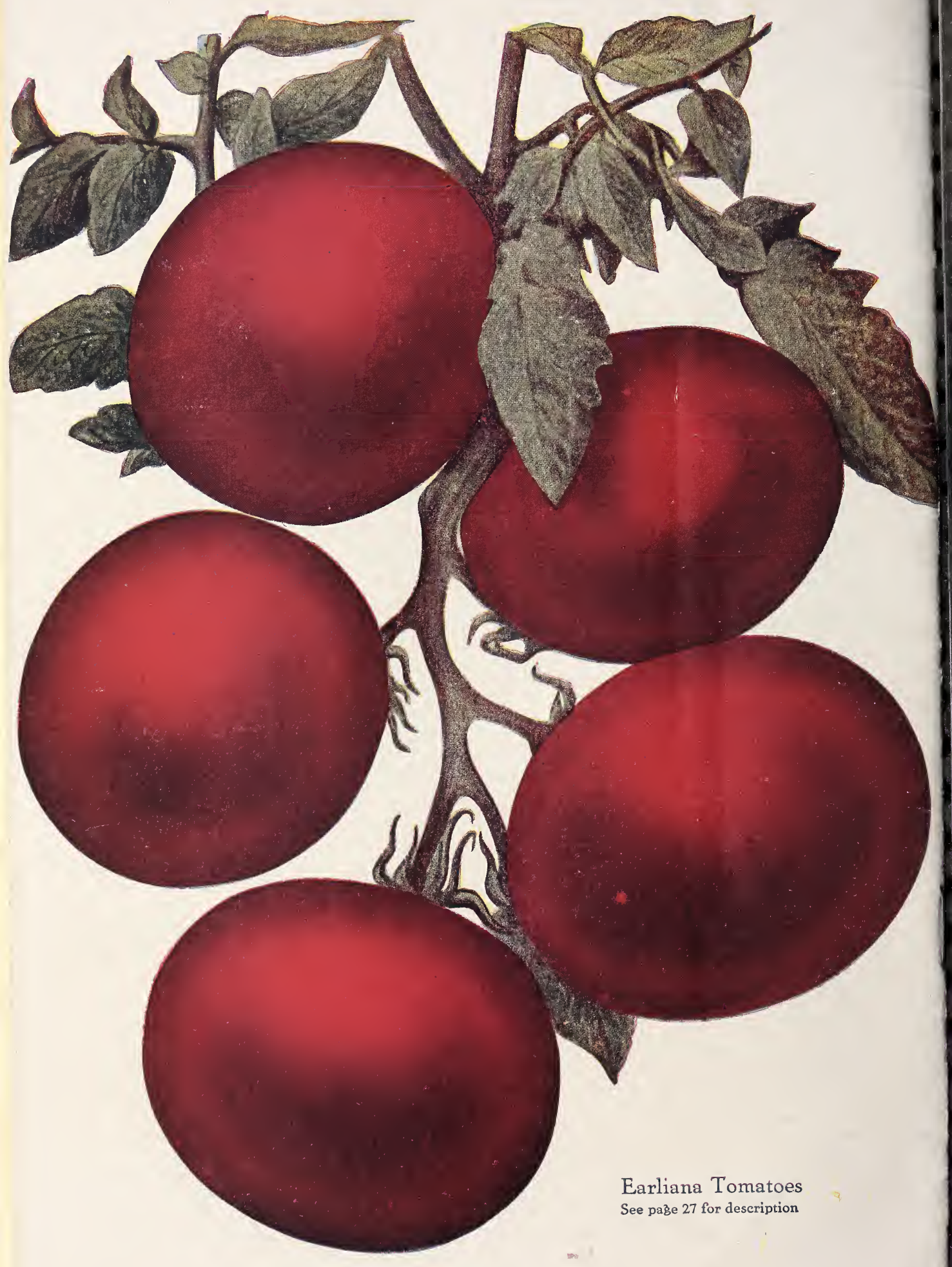

